\title{
IN OUR COMMON INTEREST: LIABILITY AND REDRESS FOR DAMAGE CAUSED TO THE NATURAL ENVIRONMENT DURING ARMED CONFLICT
}

\author{
Letetia van der Poll \\ Associate Professor, Faculty of Law, University of the Western Cape. \\ Ashraf Booley \\ Associate Lecturer, Faculty of Law, University of the Western Cape
}

\begin{abstract}
"In any armed conflict, the right of the Parties to the conflict to choose methods or means of warfare is not unlimited." 1

"The environment is not an abstraction but represents the living space, the quality of life and the very health of human beings, including generations unborn". ${ }^{2}$

"International humanitarian law aims to protect the civilian population during armed conflict and to ensure its survival. As a result, it also seeks to protect the natural environment without which human life is impossible." ${ }^{3}$
\end{abstract}

\section{INTRODUCTION}

The natural environment is generally not accorded any primary consideration during armed conflict, and yet a substantial number of provisions aimed at protecting the environment in times of war exist under international law. ${ }^{4}$ Whereas

1 This principle constitutes one of the foundational principles of international humanitarian law and is reaffirmed in Resolution XXVIII of the 20th International Conference of the Red Cross and Red Crescent held in Vienna in 1965, in Resolution 2444 of the United Nations General Assembly of 1968 and in Article 35(1) of Additional Protocol I of 1977.

2 See Advisory Opinion on the Legality of the Threat or Use of Nuclear Weapons 1996 ICJ Reports 226 para 29.

3 See "Environment and international humanitarian law" at http://www. icrc.org/eng/war-andlaw/conduct-hostilities/environment-warfare/overview (accessed 18 November 2010).

4 The International Law Commission defined the term "natural environment" as follows in 1991: "The words 'natural environment' should be taken broadly to cover the environment of the human race and where the human race develops, as well as areas the preservation of which is of 
international humanitarian law (IHL) seeks to protect certain categories of persons ${ }^{5}$ and regulate the means and methods of warfare (including the use of weapons and military tactics) ${ }^{6}$ during an armed conflict, international environmental law (IEL), broadly defined as the "corpus of international law relevant to environmental issues",7 endeavours to establish general principles for the protection of the natural environment that are both applicable and enforceable at the international level. The fusion of IHL and IEL is thus fairly evident in the sense that both these branches of public international law endeavour to protect life through the protection of the environment during armed conflict. The adoption of international instruments and their subsequent reception into domestic law have created specific rules and principles to regulate armed conflict, including the conduct of hostilities, ${ }^{8}$ some of which have acquired the status of customary international law. Similarly, the existence of the general obligation of states to ensure that activities within their jurisdiction and control (and even areas beyond their control) respect the environment of other states, is now part of the rules of international law relating to the environment. ${ }^{9}$

This article will examine, both critically and comprehensively, the effectiveness of the various principles and rules that accord general, ${ }^{10}$ specific ${ }^{11}$ and indirect ${ }^{12}$ protection to the natural environment during armed conflict, both generally and against the effects of hostilities in particular. To this end, focus will be placed on the national and international enforcement of certain mechanisms regulating the intersection between IHL and IEL, especially in so far as liability and redress for

fundamental importance in protecting the environment. These words therefore cover the seas, the atmosphere, climate, forests and other plant cover, fauna, flora and other biological elements": see GOAR 46 th Session Supplement No 10 (A/46/10) 276. This article subscribes to the same generous understanding of the term "natural environment" within the contexts of both international and non-international armed conflict.

5 These categories would include persons who do not, or who no longer, take an active part in hostilities, notably civilians and combatants who are sick, wounded, who have been captured or who have surrendered.

6 The Hague Regulations respecting the Laws and Customs of War on Land of 1899 and 1907 represent the first codification of the rules for the conduct of hostilities during armed conflict.

7 Per Koroma J (dissenting) in Advisory Opinion on the Legality of the Threat or Use of Nuclear Weapons 1996 ICJ Reports 226 para 29.

8 These would include the Non-Proliferation Treaty of 1968; the Biological Weapons Convention of 1972; the Prohibition of Military or Any Other Hostile Use of Environmental Modification Techniques of 1977; the Convention on Certain Conventional Weapons of 1980 and its five Protocols; the Chemical Weapons Convention of 1993 and its Protocols; and the Convention on Anti-Personnel Mines of 1997.

$9 \quad$ See Advisory Opinion on the Legality of the Threat or Use of Nuclear Weapons 1996 ICJ Reports 226 para 30.

10 See para 31 and accompanying footnotes below.

11 See para 4 and accompanying footnotes below.

12 See para 5 and accompanying footnotes below. 
environmental damage caused during, or as a consequence of, armed conflict are concerned.

This focus is necessitated by the fact that, to date, the only instance of state liability and redress for damage caused to the environment during armed conflict has been the Iraq/Kuwait incident. Images of the flames and the dense clouds of black smoke above the blazing oil wells in the Kuwaiti desert spurred an international outcry. Although the United Nations Charter does not expressly provide for a regime of liability - either for damage caused to the natural environment or for the depletion of natural resources during armed conflict - its provisions have been used, in an indirect manner, to hold Iraq accountable for environmental damage. ${ }^{13}$ And yet it must be borne in mind that in this instance state liability and redress emanated from Iraq's direct, blatant violation of Article 2(4) of the United Nations Charter, ${ }^{14}$ and thus the $j u s$ ad bellum, ${ }^{15}$ rather than from any violation of the rules and principles applicable during armed conflict or the jus in bello. ${ }^{16}$

\section{THE INHERENT DICHOTOMY: OFTEN NEGLECTED YET A “PRECIOUS ASSET" 17}

The International Court of Justice (the ICJ) ${ }^{18}$ has made it clear that an obligation rests on states to take environmental considerations into account during armed conflict in so far as these relate to states' military objectives. ${ }^{19}$ Thus the destruction

13 See, in particular, United Nations Security Council Resolution 687 UN Doc S/RES/687 (1991) para 16 which states that Iraq "is liable under international law for the depletion of the natural resources ... as a result of its unlawful invasion and occupation of Kuwait". Emphasis added.

14 Art 4(2) of the United Nations Charter reads: "All members shall refrain in their international relations from the threat or use of force against the territorial integrity or political independence of any state, or in any other manner inconsistent with the Purposes of the United Nations".

15 The term jus ad bellum, literally translated, means the right to initiate war. International law did not prohibit the use of force by states until 1928 with the signing of the General Treaty for the Renunciation of War, also known as the Pact of Paris or the Kellogg-Briand Pact: see, in general, Dugard J International law: A South African Perspective 3ed (2005) 501 at 501 n 4 and 526; and Gill TD \& Fleck D "History and Development of the International Law of Military Operations" in Gill TD \& Fleck D (eds) The Handbook of the International Law of Military Operations (2010) 11 at $14-20$.

16 In other words, a violation of the law applicable during armed conflict: see, in general, Dinstein $Y$ "Protection of the environment in international armed conflict" (2001) 5 Max Planck Yearbook of the United Nations Law 523 at 523-524 and at 548; and Gill \& Fleck (2010) at 20-21.

17 This term is used by Gasser: see, in particular, Gasser HP "Guidelines for Military Manuals and Instructions on the Protection of the Environment in Times of Armed Conflict" (1996) 78 No 311 International Review of the Red Cross 230 at 230-237.

18 In Advisory Opinion on the Legality of the Threat or Use of Nuclear Weapons 1996 ICJ Reports 226 para 30.

19 See also, in general, Kalshoven F \& Zegveld L Constraints on the Waging of War: An Introduction to International Humanitarian Law (2001) at 20 who, with reference to the St Petersburg 
of an oil refinery, for example, may give rise to various environmental consequences, such as causing excess oil to seep into the soil and underground water resources, thereby causing environmental degradation on a massive scale, not to mention toxic air pollution. ${ }^{20}$ There appears to be general agreement that awareness of the severe impact of armed conflict on the environment gained considerable momentum subsequent to the oil slicks on the waters of the Persian Gulf and the intentional destruction of over 600 burning oil wells in Kuwait ${ }^{21}$ at the end of the first Gulf War of 1990-1991.22

There have been at least eighteen civil wars in the last twenty years, all spurred on by the desire of armed groups, especially in Liberia, Angola and the Democratic Republic of Congo, to control and exploit natural resources such as diamonds, timber, minerals and cocoa. ${ }^{23}$ Bouvier rightly points out that awareness of the importance for humanity of a healthy environment and the determination of various agencies have produced a vast number of rules for the protection and preservation of the natural environment at both the national and international levels. ${ }^{24}$ Concern for the environment and the conservation and preservation of the natural environment typically began at the national level and progressed to the adoption of legislation pertaining to various environmental concerns, such as water, air and forestry. ${ }^{25}$ This, in turn, resulted in states adopting constitutional provisions specifically relating to the protection of the natural environment. ${ }^{26}$

Declaration of 1868 , reiterate that "[t]he only legitimate object which states should endeavour to accomplish during war is to weaken the military forces of the enemy". One method by which a belligerent party may seek to do this is by eliminating those objects which may be regarded as "military objectives" in the narrowest, most literal sense, e.g. units of the enemy armed forces and military installations such as fixed gun emplacements and munitions depots. All such objects represent legitimate military objectives.

20 See Dinstein (2001) at 523-524.

21 See, in particular, Schmidt MN "Humanitarian law and the environment" (2000) 28 Denver Journal of International Law and Policy 265 at 268.

22 See, in general, Marauhn T "Environmental damage in times of armed conflict - not 'really' a matter of criminal responsibility" (2000) 82 No 840 International Review of the Red Cross 1029 at 1031.

23 See, in particular, Mrema EM, Bruch C \& Diamond J Protecting the Environment during Armed Conflict: An Inventory and Analysis of International Law 3ed (2009) at 19.

24 See, in particular, Bouvier A "Protection of the natural environment in time of armed conflict" (1991) 73 No 285 International Review of the Red Cross 567 at 567-578 and Bouvier A "Recent studies on the protection of the environment in time of armed conflict" (1992) 74 No 291 International Review of the Red Cross 554 at 554-566.

25 Ibid.

26 Ibid. An example would be s 24 of the Constitution of the Republic of South Africa, 1996, which reads : "Everyone has the right (a) to an environment that is not harmful to their health or wellbeing; and (b) to have the environment protected, for the benefit of present and future generations, through reasonable legislative and other measures that (i) prevent pollution and ecological degradation; (ii) promote conservation; and (iii) secure ecologically sustainable development and use of natural resources while promoting justifiable economic and social development". 
Yet, although the rules of IHL apply equally to all parties to a conflict regardless of who initiated the hostilities, very few provisions address issues pertaining to the natural environment directly. The foremost (customary) instruments in IHL, notably The Hague Convention IV and Regulations respecting the Laws and Customs of War on Land of 1907 (the Fourth Hague Convention and Regulations) ${ }^{27}$ as well as the four Geneva Conventions of 1949,28 predate the widespread concern about environmental damage generated by especially the Vietnam War and the two Gulf Wars. ${ }^{29}$ Consequently, the notion of the natural environment does not appear in any IHL instrument until 1977. Additional Protocol I to the four Geneva Conventions is accordingly the first international (humanitarian law) instrument to directly address the dangers that modern warfare represents to the natural environment.

The extent to which the rules and principles of IHL relate to the protection of the natural environment will be considered next.

\section{IHL AND THE ENVIRONMENT}

The provisions of IHL relating to the protection of the environment during armed conflict can be divided into three distinct categories, namely: (a) general principles that are applicable to the protection of the environment; (b) specific provisions on the protection of the environment; and (c) provisions that provide indirect protection to the environment during armed conflict. ${ }^{30}$ Each of these categories will now critically be examined in turn.

27 The Law of The Hague determines the rights and duties of belligerents in the conduct of their military operations and limits the choice of the means of doing harm. It thus seeks to strike a balance between military necessity and humanitarian considerations. This body of law is founded on the Hague Conventions of 1899, revised in 1907. The most important of these is the Hague Convention IV Respecting the Laws and Customs of War on Land of 1907, to which is attached the Hague Regulations Respecting the Laws and Customs of War on Land of 1907. The Hague Regulations, to which South Africa is a party, are generally accepted as forming part of customary international law: see, in particular, the judgment of the Nuremburg Military Tribunal (1947) 41 American Journal of International Law 172.

28 These include the Geneva Convention for the Amelioration of the Condition of the Wounded and Sick in Armed Forces in the Field of 1949 (the First Geneva Convention), the Geneva Convention for the Amelioration of the Condition of Wounded, Sick and Shipwrecked Members of Armed Forces at Sea of 1949 (the Second Geneva Convention), the Geneva Convention Relative to the Treatment of Prisoners of War of 1949 (the Third Geneva Convention) and the Geneva Convention Relative to the Protection of Civilian Persons in Time of War of 1949 (the Fourth Geneva Convention).

29 See, in particular, Mrema et al (2009) at 10.

$30 \quad$ Ibid at 11. 


\subsection{General principles of IHL applicable to the protection of the environment during armed conflict}

The general principles of international law applicable in armed conflict are regarded as a source of law in accordance with Article 38(1) of the Statute of the ICJ. ${ }^{31}$ These principles are thus applicable to all states, either as a direct consequence of their ratification by States Parties or by virtue of the fact that these international instruments have acquired the status of customary law. In this context the Martens Clause $^{32}$ is of particular significance. In due recognition of the fact that treaty law would be hard pressed to resolve all future challenges presented by IHL, the Martens Clause insisted that the conduct of hostilities were always to "be governed by existing principles of international [humanitarian] law". ${ }^{33}$ According to the United Nations Environment Programme (UNEP), the Martens Clause thus "broadens the range of applicable norms governing conduct during armed conflict beyond those that are laid out in treaty instruments". ${ }^{34}$ It follows that the Martens Clause is to be regarded as one of the central principles of IHL which would extend protection to the natural environment during armed conflict in instances where no explicit provisions to this effect exist either in customary IHL or in treaty law. ${ }^{35}$

Other fundamental principles of IHL which relate to the protection of the environment during armed conflict include the principles of distinction, military necessity, proportionality and humanity. Although essential to both the scope and object of this article, much of what has been written about these four fundamental (and therefore general) principles of IHL are trite law, and consequently, each of these principles will only be considered briefly.

31 Article 38(1) of the Statute of the ICJ describes the sources of international law as "(a) international conventions (treaties), whether general or particular; (b) international custom, as evidence of a general practice accepted as law; (c) the general principles of law recognised by civilized nations; and (d) judicial decisions and the teachings of the most highly qualified publicists, as subsidiary means for the determination of rules of law." See also, in general, Strydom HA "Customary international law: The legacy of false prophets" (1994) 27 Comparative and International Law Journal of Southern Africa 276 at 276 and Roberts AE "Traditional and modern approaches to customary international law: A reconciliation" (2001) 95 American Journal of International Law 757 at 757-791.

32 The Martens Clause is a general provision that was adopted at the first Hague Peace Conference in 1899 and was subsequently also inserted into the Preamble to The Hague Conventions of 1907. For a detailed discussion of the Martens Clause and its significance, see Meron T Human Rights in Internal Strife: Their International Protection (1987) at 13.

33 See, in particular, Kalshoven \& Zegveld (2001) at 22.

34 See, in particular, Mrema et al (2009) at 12.

35 Ibid. These sentiments are also echoed in Article 1(2) of Additional Protocol I which reads: "In cases not covered by this Protocol or by other international agreements, civilians and combatants remain under the protection and authority of the principles of international law derived from established custom, from the principles of humanity and from the dictates of public conscience". The Preamble to Additional Protocol II expresses a similar sentiment: "In cases not covered by the law in force, the human person remains under the protection of the principles of humanity and the dictates of public conscience". 


\subsection{The principle of distinction}

The principle of distinction is regarded as one of the first to be applied during armed conflict: distinctions necessarily need to be drawn between combatants and members of the civilian population as well as between military objects and civilian objects. ${ }^{36}$ The principle of distinction furthermore prohibits indiscriminate attacks and any direct attacks against civilians. ${ }^{37}$ Article 52(2) of Additional Protocol I expressly stipulates that attacks shall be limited strictly to military objectives. In so far as objects are concerned, military objectives are limited to

"those objects which by their nature, location, purpose or use make an effective contribution to military action and whose total or partial destruction, capture or neutralization, in the circumstances ruling at the time, offers a definite military advantage". ${ }^{38}$

Given the non-military nature of environmental sites and protected areas, the targeting of such areas would, therefore, be contrary to the principle of distinction and in violation of Article 52(2) of Additional Protocol I. The application of the principle of distinction within the context of the environment is not without controversy, however. UNEP is, for example, of the opinion that its application may encounter distinct practical difficulties. So, although the targeting of power plants and chemical factories may well cause severe environmental effects, such attack could still be sanctioned by Article 52(2) of Additional Protocol I and interpreted as constituting a "direct contribution to ongoing military action". ${ }^{39}$ Article 52(2) of Additional Protocol I furthermore creates difficulties in its interpretation, especially in so far as the distinction between a direct and an indirect military advantage is concerned, ${ }^{40}$ and thus the environment may in fact be rendered vulnerable during wartime by virtue of the degree of uncertainty created by Article 52(2) of Additional Protocol I.

36 See, in particular, Art 48 of Additional Protocol I which reads: "In order to ensure respect of and protection of the civilian population and civilian objects, the Parties to the conflict shall at all times distinguish between the civilian population and combatants and between civilian objects and military objectives and accordingly shall direct their operations only against military objectives". Emphasis added.

37 See Dinstein (2001) at 524-525. See also Art 57(5) of Additional Protocol I which contains an absolute prohibition on attacks against the civilian population, civilians or civilian objects.

38 Emphasis added.

39 See, in particular, Mrema et al (2009) at 13.

40 Ibid. 


\subsection{The principle of military necessity}

The principle of military necessity, first articulated in Article 14 of the Lieber Code of 1863, suggests that the "use of force is only justified to the extent it is necessary to achieve a defined military objective", ${ }^{41}$ and thus this principle would proscribe conduct which have no direct and/or obvious military purpose. ${ }^{42}$ As Sassòli so aptly states:

"IHL is a compromise between humanity and military necessity, a compromise which cannot always satisfy humanitarian agendas, but which has the immense advantage that it has been accepted by states as law that can be respected, even in war".43

The principle of military necessity is contained in the Fourth Hague Convention. To this end, Article 23(g) refers to enemy property and stipulates that it is forbidden "to destroy or seize the enemy's property, unless such destruction or seizure be imperatively demanded by necessities of war". This provision is of particular relevance to the natural environment as "enemy property" may include protected areas, environmental goods and high-value natural resources. These resources could thus be granted indirect protection through the principle of military necessity as articulated in Article 23(g) of the Fourth Hague Convention.

\subsection{The principle of proportionality}

Often misunderstood, ${ }^{44}$ the principle of proportionality requires that a distinction be drawn between the different ways in which it limits the use of force in armed conflict. The principle of proportionality is thus thought to restrict both the use of force by states (the jus ad bellum) and the right to choose the most appropriate means and methods of warfare (the jus in bello). ${ }^{45}$ According to Cannizzaro, proportionality has a two-fold purpose in respect of the jus ad bellum, in that it both identifies the instances in which the unilateral use of force by a state is permissible

41 Ibid.

42 See, in general, Dinstein (2001) 523 n 2.

43 Sassòli M "The implementation of international humanitarian law: Current and inherent challenges" in TLH McCormack (ed) Yearbook of International Humanitarian Law (2009) 45 at 50. Emphasis added.

44 See, in general, Solis GD "Law of armed conflict's four core principles" in GD Solis The Law of Armed Conflict: International Humanitarian Law in War (2010) 250 at 284-283 and Bothe M, Bruch C, Diamond J \& Jensen J "International law protecting the environment during armed conflict: gaps and opportunities" (2010) 92 No 879 International Review of the Red Cross 569 at 577-578.

45 Although clear in theory, this distinction tends to become obscured in practice: see, in general, Cannizzaro E "Contextualizing proportionality: jus ad bellum and jus in bello in the Lebanese war" (2006) 88 No 864 International Review of the Red Cross 779 at 781. 
and determines the "intensity and the magnitude of military action". ${ }^{46}$ In the jus in bello, by contrast, the notion of proportionality is governed by the assumption that the parties to the conflict are equal in status, coupled with the related IHL principle which gives effect to the "respect owed by each party to the conflict to interests and values of a humanitarian nature". 47

Article 57 of Additional Protocol I addresses the principle of proportionality. In essence, the principle of proportionality would be violated in instances where socalled "collateral casualties or damage" 48 would be deemed as "excessive in relation to the concrete and direct military advantage anticipated". ${ }^{49}$ Yet it is equally true that while IHL carefully articulates what would constitute a legitimate target, the type of weapon to be used when launching an attack on a particular military objective is not regulated. Article 57 of Additional Protocol I thus only mandates a balancing of military necessity and unnecessary suffering so that the principle of proportionality is satisfied.50 And, in the words of the ICJ, "[r]espect for the environment is one of the elements that go to assessing whether an action is in conformity with the principles of necessity and proportionality". ${ }^{51}$

It could therefore be argued that, when the environment is damaged during armed conflict, such damage could well be seen as a "disproportionate response to a perceived threat" 52 and thus constitute a violation of Article 57 of Additional Protocol I. This is certainly the opinion of UNEP in respect of the first Gulf War, in which environmental damage resulted from of the intentional burning of oil fields and the subsequent spilling of millions of gallons of oil into the Gulf Sea. ${ }^{53}$

\subsection{The principle of humanity}

Article 23(e) of the Hague Regulations articulates one of the fundamental objectives of IHL, namely to "mitigate the human suffering caused by war". ${ }^{44}$ This fundamental objective, referred to as the principle of humanity, finds expression in the rules

$46 \quad$ Ibid. See also, in general, Dinstein (2001) at 524.

47 Ibid 785. See also, in general, Quéguiner JF "Precautions under the law governing the conduct of hostilities" (2006) 88 No 864 International Review of the Red Cross 793 at 814.

48 Ibid 801.

49 See, in particular, Article 57(2)(a)(iii) of Additional Protocol I.

50 See, in particular, Infeld DL "Precision-guided munitions demonstrated their pinpoint accuracy in desert storm; but is a country obliged to use precision technology to minimize collateral civilian injury and damage?" (1992) 26 (1) George Washington Journal of International Law and Economics 109 at $134-135$.

51 In Advisory Opinion on the Legality of the Threat or Use of Nuclear Weapons 1996 ICJ Reports 226 para 30.

52 See, in particular, Mrema et al at 13.

53 Ibid.

54 See, in particular, Kalshoven \& Zegveld (2001) at 12. See also, in general, Solis (2010) at 22. 
which seek to protect those who do not (or who no longer) ${ }^{55}$ directly participate in the hostilities as well as in the various rules which regulate the means and methods of warfare. It follows that a party to an armed conflict cannot use prohibited methods of warfare against a civilian population and that the intentional contamination of natural and agricultural resources would constitute a violation of Article 23(e). Furthermore, the express reference contained in the Martens Clause to the "law of humanity" has led UNEP to conclude that "environmental considerations" (as proposed by the International Union for Conservation of Nature (the IUCN)), 56 "clearly seeks to build on the principle of humanity and the dictates of public conscience to protect the environment in the absence of specific treaty law". ${ }^{57}$

There seems to be general agreement that international agreements pertaining to the environment and the rules of customary international law may continue to find application in times of war, but only to the degree that these are not in violation of the "applicable law of armed conflict". ${ }^{58}$ Furthermore, environmental obligations that are binding on states which are not a party to an armed conflict, and that extend beyond their national jurisdiction, are not affected by the existence of armed conflict but, again, only "to the extent that those obligations are not inconsistent" with IHL. ${ }^{59}$

In cases not specifically addressed by either national or international agreements, the environment thus remains generally under the protection of the principles of custom, humanity and the dictates of public conscience, and therefore the rules of (international) environmental law may well continue to be applicable during an armed conflict.60

Provisions specifically aimed at protecting the environment during armed conflict will be considered next.

$55 \quad$ See $\mathrm{n} 5$ above.

56 See, in particular, International Union for Conservation of Nature "A Martens clause for environmental protection" World Conservation Congress Resolution 2.97 (October 2000) Chapter 5.3(ii) 2.

57 See, in particular, Mrema et al (2009) at 13. UNEP refers by way of example to the ongoing conflict in Darfur, Sudan, of an armed conflict that would constitute inhumane means of warfare.

58 See, in particular, Art II(5) ("General Principles of International Law") of the ICRC Guidelines for Military Manuals and Instructions on the Protection of the Environment in Times of Armed Conflict. See also, in general, Gasser (1996) at 230-231.

59 Examples would include neighbouring states and the High Seas, respectively. This express formulation and specific examples are contained in Art II(5) ("General Principles of International Law") of the ICRC Guidelines for Military Manuals and Instructions on the Protection of the Environment in Times of Armed Conflict.

60 See, in general, Gasser HP "For better protection of the natural environment in armed conflict: A proposal for action" (1995) 89 American Journal of International Law 637 at 638. 


\section{PROVISIONS SPECIFICALLY AIMED AT PROTECTING THE ENVIRONMENT DURING ARMED CONFLICT}

\subsection{Articles 35(3) and 55(1) of Additional Protocol I of 1977}

UNEP rightly points out that the negotiations pertaining to Additional Protocol I to the four Geneva Conventions were the direct result of various wars of national liberation as well as the Vietnam War. ${ }^{61}$ Additional Protocol I thus applies to international armed conflicts which expressly include "fighting against colonial domination" and "racist regimes in the exercise of the right to self determination".62 The growing concern about the environment, as well as concerns over military tactics employed during these conflicts, led to the inclusion of two provisions in Additional Protocol I that explicitly address environmental damage, namely Article 35(3) and Article 55.

Article 35 encapsulates the basic rules relating to the means and methods of warfare. Article 35(3) expressly states that

"it is prohibited to employ methods or means of warfare which are intended, or may be expected, to cause widespread, long-term and severe damage to the natural environment".

This would include so-called "collateral damage" 63 to the environment, and Reyhani rightly points out that Article 35(3) applies to situations in which the natural environment is damaged through the intentional use of methods or means of warfare and where such consequences are foreseeable. ${ }^{64}$ Article 55, in turn, provides specific protection for the environment within the context of the general protection granted to civilian objects, and thus any attacks against the natural environment by way of reprisals are prohibited. ${ }^{65}$ In particular, Article 55(1) states that

"[c]are shall be taken in warfare to protect the natural environment against widespread, long-term and severe damage. This protection includes a prohibition of the use of methods or means of warfare which are intended or may be expected to cause such damage to the natural environment and thereby to prejudice the health or survival of the population."

The common principles enshrined in Article 35(3) and Article 55 thus relate to the prohibition of warfare that may cause widespread, long-term and severe damage to the natural environment. ${ }^{66}$ According to UNEP, the scope of these provisions

61 See, in particular, Mrema et al (2009) at 11. See also, in particular, the Convention on the Prohibition of Military or Any Other Hostile Use of Environmental Modification Techniques of 1976, signed in Geneva on 18 May 1977, which entered into force on 5 October 1978.

62 See, in particular, Art 1(4) of Additional Protocol I of 1977.

63 See, in particular, Mrema et al (2009) at 11.

64 See Reyhani R "The protection of the environment during armed conflict" (2007) 14 No 2 Missouri Environmental Law and Policy Review 323 at 329.

65 See, in particular, Bouvier (1991) at 567-578.

66 While there is some similarity in their formulation, Art 35(3) and Art 55(1) of Additional 
initially appears to be extensive. Yet Article 35 neither defines the term "natural environment" nor the terms "widespread", "long-term" and "severe damage". The precise meaning of these terms in Article 35(3) is crucial as they establish a threefold threshold which must be crossed simultaneously to establish liability under international law. There would, for example, be no liability where damage to the environment during armed conflict is widespread, but not severe or long-term. The liability regime which Article 35(3) seeks to establish is difficult to determine, not only because of the lack of clarity about key definitions, but also due to the fact that the three thresholds are difficult to satisfy concurrently. Article 35(3) therefore insists on a threshold that is not only high and uncertain, but also of an imprecise nature.

It would appear that Article 55 must be interpreted as a "governing principle" 67 that requires that the effects (or consequences) of permitted actions ${ }^{68}$ may not result in escalating damage or produce the expressly prohibited widespread, longterm and severe damage to the natural environment. As a governing principle, Article 55 thus extends beyond Article 35 in so far as it relates to issues of health or survival of the civilian population. This is to be welcomed, as Article 55 could then possibly be interpreted to also provide for instances where environmental damage is not only caused directly by combatants (or as a consequence of their actions), but also by the actions of civilians and refugees. Such situations may, for example, arise in an armed conflict where civilians or refugees resort to the destruction of wildlife, as was the case in the Democratic Republic of Congo. 69

Similarly, Article 35(3) would appear not to impose any significant limitation on combatants waging conventional warfare. Article 35(3) thus seems primarily directed to high-level decision makers and would affect such unconventional means

Protocol I differ in respect of their emphasis: see, in general, Hulme K "Taking care to protect the environment against damage: a meaningless obligation?" (2010) 92 No 879 International Review of the Red Cross 675 at 676.

67 This term is suggested by Reyhani: see Reyhani (2007) at 329.

68 Permitted actions would exclude reprisals which are expressly excluded by Art 55(2) of Additional Protocol I.

69 The Okapi Wildlife Reserve (the Reserve) in the Democratic Republic of Congo (the DRC) was placed on the list of World Heritage in Danger in 1998, a mere year after being granted World Heritage status, as a direct result of the armed conflict in the DRC in early 1997 which had led to the looting of facilities and equipment donated by international conservation non-governmental organizations, the killing of elephants, incursions by thousands of gold and coltan miners and by hunters and cultivators. By 2001, exploitation of the Reserve by armed militias, miners and hunters had decimated the animal population around all camps and the park was too dangerous to visit. That year the IUCN, United Nations and UNEP responded to pleas from staff and nongovernmental organisations for international pressure to stop the destruction and help to restore funds, morale and order: see http://www.eoearth.org/article/Okapi Faunal Reserve, Democratic Republic of Congo (accessed 3 February 2011). 
of warfare as the use of herbicides and chemical agents which may well produce widespread, long-term and severe damage to the natural environment. ${ }^{70}$

Articles 35 and 55 are, of course, binding on all States Parties to Additional Protocol I. Yet Additional Protocol I has still to achieve universal ratification, a fact which has the potential to severely detract from the effectiveness of its liability regime. Several recent international armed conflicts which have caused massive destruction to the environment have been waged by non-State Parties to Additional Protocol I, notably the United States, Iraq and the United Kingdom. ${ }^{71}$ And even in instances where Additional Protocol I has been ratified, it has been subjected to declarations and reservations intended to limit state liability. Some states have, for instance, maintained that the rules of Additional Protocol I would not apply to nuclear weapons but to conventional weapons only. ${ }^{72}$

Reyhani points out that it is unclear whether Articles 35 and 55 could be considered to be part of customary international (humanitarian) law. There exists some evidence, however, to suggest that these provisions have indeed acquired the status of customary international law. The fact that the cause of damage to the environment has been expressly prohibited in many state military manuals, ${ }^{73}$ coupled with the fact that any transgression of these provisions has been legislated as an offence under domestic law, may well underscore such an argument. ${ }^{74}$ Submissions before the ICJ furthermore show that states consider Articles 35(3) and 55 to have indeed acquired the status of customary international law..$^{75}$ Any party to a conflict must accordingly observe these two provisions or must avoid using methods or means of warfare that would destroy, or could have disastrous effects on, the environment. ${ }^{76}$ Moreover, the prohibition of wilful serious damage to the environment during armed conflict could well be said to have evolved into a peremptory norm of international law, ${ }^{77}$ and Article 8 of the Rome Statute of the

70 See, in particular, Mrema et al (2009) 10 at 11.

71 These conflicts have included the United States coalition and Iraq (1990-1991); Iran and Iraq (1980-1988); and the United Kingdom and Argentina (1982): see, in general, Roberts A \& Guelff R "International armed conflicts" in Roberts A \& Guelff R (eds) Documents on the Laws of War 3ed (2000) 419 at 421.

72 Ibid. States such as Belgium, Canada, Germany and the United States, in particular, have expressed this view.

73 These include the military manuals of Argentina, Australia, Belgium, Benin, Canada, France, Germany, Italy, the Netherlands, New Zealand, Russia, Spain, Sweden, Switzerland, Togo, the United Kingdom, the United States and Yugoslavia: see, in particular, Henckaerts JM and Doswald-Beck L (eds) Customary International Humanitarian Law Vol I (2005) at 152 n 52.

74 See, in particular, Reyhani (2007) at 330.

75 See Advisory Opinion on the Legality of the Threat or Use of Nuclear Weapons 1996 ICJ Reports 226 para 31.

76 See, in particular, Reyhani (2007) at 330 and Henckaerts \& Doswald-Beck Vol I (2005) at 152.

77 See, in particular, Uhlmann EVM "Protection of the global environment: Developing criteria for peremptory norms" available at http://www.heinonline.org (accessed 6 August 2010). 
International Criminal Court (the ICC) indeed criminalises wilful damage to the environment during armed conflict as a war crime. ${ }^{78}$

The liability regime established under Additional Protocol I is, however, some cause for concern. Although Article 89 provides for the cooperation of States Parties and the United Nations to act in the case of serious violations of Additional Protocol I,79 and albeit that Article 90 establishes an International Fact-Finding Commission (the Commission) to enquire into allegations of grave breaches of Additional Protocol I, States Parties have to agree to accept the competence of the Commission. ${ }^{80}$ But since Additional Protocol I does not apply to non-international armed conflicts, and although the Commission has offered to extend its services to violations during non-international armed conflicts, it has yet to receive any request from a State Party to do so. ${ }^{81}$ This is indeed cause for concern, given that noninternational armed conflicts, involving non-state actors who are not parties to international instruments, are known to have a serious and continuing impact on the natural environment. ${ }^{82}$

Finally, the liability regime established under Additional Protocol I also appears inadequate as it offers no guidelines as to how, or even to whom, compensation should be paid. Although Article 91 provides for state responsibility in the case of violations and for state liability to pay compensation, "if the case demands", for the actions of its armed forces, ${ }^{83}$ it cannot be determined from the provisions of Additional Protocol I alone whether compensation would include restitution or whether compensation should be in the form of a monetary award only. Similarly, while Article 85(4)(d) lists the destruction of "clearly-recognised historic monuments, works of art or places of worship which constitute the cultural or spiritual heritage of peoples", which are not military objectives, as a grave breach of Additional Protocol I, and Article 85(5) provides that such acts are war crimes for

78 Art 8 of the Rome Statute prohibits "Intentionally launching an attack in the knowledge that such attack will cause incidental loss of life or injury to civilians or damage to civilian objects or widespread, long-term and severe damage to the natural environment which would be clearly excessive in relation to the concrete and direct overall military advantage anticipated". On the significance of this, see para 62 .

79 Art 89 of Additional Protocol I reads: "In situations of serious violations of the [Geneva] Conventions or of this Protocol, the High Contracting Parties undertake to act, jointly or individually, in co-operation with the United Nations and in conformity with the United Nations Charter".

80 Art 90(1)(b) expressly stipulates that not less than twenty High Contracting Parties have to agree to accept the competence of the International Fact-Finding Commission.

81 See, in particular, Roberts \& Guelff (2000) at 421.

82 Ibid.

83 Art 91 of Additional Protocol I reads: "A Party to the conflict which violates the provisions of the [Geneva] Conventions or of this Protocol shall, if the case demands, be liable to pay compensation. It shall be responsible for all acts committed by persons forming part of its armed forces". 
which there are to be both penal and disciplinary sanctions, there again exists no provision to govern compensation. ${ }^{84}$

The significance of the Convention on the Prohibition of Military or Any Other Hostile Use of Environmental Modification Techniques of 1976 (the ENMOD Convention) will be examined next.

\subsection{The ENMOD Convention}

The ENMOD Convention was adopted by the United Nations General Assembly in 1976 and opened for signature in 1977.85 According to UNEP the ENMOD Convention was created in direct response to the "military tactics employed by the United States during the Viet Nam War". ${ }^{86}$ The object of the Convention is to prohibit the use of environmental modification techniques, defined under Article $2,{ }^{87}$ as a means of warfare. Article 1 of the Convention specifically requires that

"[e]ach State Party to this Convention undertakes not to engage in military or any other hostile use of environmental modification techniques having widespread, long-lasting or severe effects as a means of destruction, damage or injury to any other State Party".

Article 1(2) of the Convention also requires State Parties not to assist, encourage or induce any state, group of states or international organisations to engage in such activities. ${ }^{88}$ By virtue of Article 4, states are instructed to take measures to "prohibit

84 Art 75 of the Rome Statute may provide a solution to the problems endemic to the liability regime of Additional Protocol I, at least in so far as individual perpetrators are concerned. Art 75(1) of the Rome Statute expressly stipulates that the ICC shall "establish principles relating to reparations to, or in respect of, victims, including restitution, compensation and rehabilitation". Art 75(2) furthermore provides that the ICC "may make an order directly against a convicted person specifying appropriate reparations to, or in respect of victims, including restitution, compensation and rehabilitation". Where appropriate, Art 75(2) also provides that the "award for reparations can be made through the Trust Fund provided for in art 79" of the Rome Statute. Since Art 75(6) expressly stipulates that "[n]othing in this article shall be interpreted as prejudicing the rights of victims under national or international law", the general principles on state responsibility and international law remedies in case of a violation of the provisions of Additional Protocol I would presumably also remain available.

85 Signed in Geneva on 18 May 1977 and entered into force on 5 October 1978. See also, in general, the Sunshine Project "ENMOD: hostile environmental modification" available at http://www.sunshineproject.org/enmod (accessed 3 October 2010).

86 See, in particular, Mrema et al (2009) at 12. According to UNEP, these military tactics related to "large-scale environmental modification techniques" which included techniques capable of "provoking earthquakes, tsunamis, and creating a change in weather patterns" (so-called "geophysical warfare"): ibid 12. Chemical defoliants which caused "extensive human suffering" and "long-term environmental contamination" were also used, with over 55,000 tonnes of chemical defoliants being targeted to forests and crops in Vietnam: ibid $12 \mathrm{n} 10$.

87 Art 2 of the ENMOD Convention defines environmental modification techniques as "any technique for changing - through the deliberate manipulation of natural processes - the dynamics, composition or structure of the Earth, including its biota, lithosphere, hydrosphere and atmosphere, or of outer space".

88 See, in general, Reyhani (2007) at 326-327. 
and prevent" any violations. The Convention allows for complaints to be lodged with the United Nations Security Council (the Security Council) where a state acts in breach of its provisions ${ }^{89}$ and the Security Council "may" initiate investigations on the basis of complaints received. ${ }^{90}$ Support is to be given to any requesting state "if the Security Council decides that such a party has been harmed or is likely to be harmed as a result of the violation of the Convention". ${ }^{91}$

Notable differences exist between Additional Protocol I and the ENMOD Convention. These relate in particular to the intended objects of and thresholds for environmental damage. In so far as the intended objects of the two instruments are concerned, Article 35(3) of Additional Protocol I seeks to "protect the natural environment"; by contrast, the ENMOD Convention "prohibit[s] the use of techniques that will turn the environment into a 'weapon'". ${ }^{92}$ Furthermore, Article 2 of the Convention requires that the damage has to be "widespread, long-lasting or severe". ${ }^{93}$ According to UNEP, the environmental damage must be "widespread" where the damage encompassed "an area on the scale of several hundred square kilometres"..$^{44}$ In the case of the Convention the term "long-lasting" would refer to a "period of months or approximately a season", ${ }^{95}$ whereas in the case of Additional Protocol I, "long-term" would apparently mean "decades". 96

It could certainly be argued that the ENMOD Convention has been a success and has acted as an effective environmental instrument, as no other large scale environmental modification tactics have been reported subsequent to the Vietnam War. The Convention is also rather innovative to the extent that it prohibits technology which has not yet been invented, ${ }^{97}$ and marks an improvement over Additional Protocol I in the sense that it provides a definition for each of the three

89 See Art 5(3) of the Convention which provides: "Any State Party to this Convention which has reason to believe that any other State Party is acting in breach of obligations deriving from the provisions of the Convention may lodge a complaint with the Security Council of the United Nations. Such a complaint should include all relevant information as well as all possible evidence supporting its validity".

90 See Art 5(4) of the Convention which stipulates: "Each State Party to this Convention undertakes to cooperate in carrying out any investigation which the Security Council may initiate, in accordance with the provisions of the Charter of the United Nations, on the basis of the complaint received by the Council. The Security Council shall inform the States Parties of the results of the investigation".

91 See Art 5(5) of the Convention which reads: "Each State Party to this Convention undertakes to provide or support assistance, in accordance with the provisions of the Charter of the United Nations, to any State Party which so requests, if the Security Council decides that such Party has been harmed or is likely to be harmed as a result of violation of the Convention".

92 See, in particular, Mrema et al (2009) at 12.

93 Emphasis added.

94 See, in particular, Mrema et al (2009) 10 at 12.

95 This particular interpretation was suggested by the United Nations Committee of the Conference on Disarmament: see, in particular, Bothe et al (2010) at 572.

96 See, in particular, Mrema et al (2009) at 12.

97 See, in particular, Roberts \& Guelff (2000) at 408. 
thresholds. The Convention also lowers the standard of liability by the use of the word "or" in the phrase "widespread, long-lasting or severe". This means that all three requirements do not have to be met before a state is deemed to be in violation of the prohibition. A violation of one requirement would thus be sufficient to establish liability.

Despite the marked improvements and innovative nature of the ENMOD Convention, it also contains some critical flaws. First, the Convention lacks a flawless mechanism for legal redress. For instance, the Convention allows complaints to be made to the Security Council but does not necessarily impose any obligation on the Security Council to investigate the matter. Also, since the Security Council is a highly political (and politicised) body, it may well choose not to investigate politically powerful states, including the five permanent members who possess a veto power. ${ }^{98}$ The environmental damage caused by Iraq during the first Gulf War is a case in point. Although Iraq and Kuwait were not signatories to the Convention, the environmental damage caused by Iraq was addressed by the Security Council. Iraq was responsible for the spilling of seven million barrels of Kuwaiti oil into the Persian Gulf and had set alight more than 600 oil well heads. ${ }^{99}$ The consequences were catastrophic, with vast quantities of oil flowing into the Persian Gulf.

In terms of Resolution 687 (which set out the cease-fire conditions in the Gulf War), the Security Council held Iraq responsible for "any direct loss, damage, including environmental damage, and the depletion of natural resources" inflicted during the armed conflict between Iraq and Kuwait. ${ }^{100}$ In addition, a Compensation Fund (generated by revenues from Iraqi petroleum exports) and a Compensation Commission was established by the Security Council to administer claims against Iraq ${ }^{101}$ (albeit that not all delegates were of the opinion that international law should apply).102 The introduction of Resolution 687 by the Security Council thus created a foundation by which to address the consequences of future conflicts and is intended as a deterrent for states to become embroiled in conflict situations.

98

99 See, in particular, Schmidt MN "Humanitarian law and the environment" (2000) 28 Denver Journal of International Law and Policy 265 at 268.

100 United Nations Security Council Resolution 687 UN Doc S/RES/687 (1991). Resolution 687, divided into nine sections, inter alia urged Iraq and Kuwait to respect the boundary between the two countries and stated that Iraq was liable for any loss, damage and injury inflicted upon Kuwait, demanding further that Iraq hand over any remaining property seized from Kuwait. The resolution was passed, after an extended meeting on 3 April 1991, by 12 votes to one against (Cuba) with two abstentions (Ecuador and Yemen). Iraq accepted the provisions of the resolution on 6 April 1991.

101 United Nations Security Council Resolution 692 UN Doc S/RES/0692 (1991) adopted on 20 May 1991. See also (1991) 30 International Legal Materials 864. The Compensation Commission had by the late 1990s already awarded the Kuwaiti authorities hundreds of millions of dollars for the cost of extinguishing the well-head fires: see, in particular, Alford RP "Well blowout control claim" (1998) 92 American Journal of International Law 287 at 288. 
Although Security Council Resolution 687 has reinforced awareness among states that they may be held accountable should they act in violation of the jus ad bellum, it has also indirectly secured enhanced protection for the natural environment during an armed conflict. 103

Arguably, the motivation for choosing the Security Council to investigate complaints made in terms of the ENMOD Convention is to be found in its ability to impose sanctions under Article 41 of the United Nations Charter. However, whatever the true motivation may be for electing the Security Council to investigate complaints in its discretion, this particular mechanism for redress under the Convention appears to be rather inadequate in the circumstances.

Secondly, the protection afforded by Article 1(2) of the Convention is also not sufficient in so far as it requires of States Parties not to assist, encourage or induce any state, group of states or international organisations to engage in the proscribed activities. Recent developments in international law reveal, however, that states may choose to support organisations who engage in terrorist activities and (other) non-state actors who do not squarely fall into any of the proscribed categories. The question thus arises whether or not a state that induces non-state actors to carry out environmental warfare would fall foul of the provisions of the Convention.

Thirdly, some concern exists regarding the scope of the Convention. Dinstein rightly points out that the Convention's protection only applies to States Parties. ${ }^{104}$ Thus, if environmental modification is done outside the territory of a State Party (such as on the High Seas), the Convention would not apply. Article 1(1) thus does not consider the fact that the results of environmental modification can have a trans-boundary effect. Consequently, in instances where the trans-boundary effect of environmental modification in armed conflict is felt by a state that is not a party to the Convention, there would be no liability under its proscriptive regime.

There also exists no liability for damage to the environment where environmental modification occurs accidentally or as a consequence of a particular means and/or method of warfare. This is due to the fact that Article 2 of the Convention provides a mens rea requirement insofar as the modification must be "deliberate". This provision marks a departure from the additional element of foreseeability ("may be expected") which is contained in Article 35(3) of Additional Protocol I.

Finally, the Convention also provides no redress for a breach of its provisions. ${ }^{105}$ There is no reference to either compensation or (legal) sanction. ${ }^{106}$ When harm

103 See, in particular, Roberts \& Guelff (2000) at 408.

104 See, in particular, Dinstein (2001) at 540. Although only applicable to States Parties, there appears to be general agreement that the environment is entitled to "special protection during both international and non-international armed conflicts": see, in particular, Gill \& Fleck (2010) at 266.

105 See Chamorro SP \& Hammond E Addressing Environmental Modifications in post-Cold War Conflict (2001) available at http://www.edmonds-institute.org/pimiento.html (accessed 12 
occurs, support assistance is all that is required, and even in such instances, the Security Council has to determine that a State Party has been harmed or is likely to be harmed".

Applicable provisions of the Convention on Prohibitions or Restrictions on the Use of Certain Conventional Weapons Which May Be Deemed to be Excessively Injurious or to Have Indiscriminate Effects of 1980 (the Convention on Conventional Weapons) and its three Protocols will be examined next.

\subsection{The Convention on Conventional Weapons and Annexed Protocols}

The Convention on Conventional Weapons and its three annexed Protocols were adopted on 10 October 1980.107 The fourth paragraph of its Preamble reiterates the "triple cumulative standard"108 contained in Article 35(3) of Additional Protocol I and expressly stipulates that "it is prohibited to employ methods or means of warfare which are intended, or may be expected, to cause widespread, long-term and severe damage to the natural environment".

Of particular importance is an amendment to Article 1 of the Convention on Conventional Weapons, brought about in 2001, which refers to common Article 3 to the four Geneva Conventions and thus extends the field of application to noninternational armed conflicts. ${ }^{109}$

Of the three annexed Protocols to the Convention on Conventional Weapons, two are of specific relevance to the protection of the environment during armed conflict, notably the Protocol on Prohibitions or Restrictions of the Use of Mines, Booby Traps and Other Devices (Protocol II) and the Protocol on Prohibitions or Restrictions and Use of Incendiary Weapons (Protocol III). To this end, Protocol II prohibits the use of booby traps on "historic monuments, works of art or places of worship which constitute the cultural or spiritual heritage of peoples' and animals". ${ }^{110}$ Article 2(4) of Protocol III prohibits the use of incendiary weapons on the "forest or other kinds of plant cover", but an exception is allowed where such forests or plants are used to "cover, conceal or camouflage combatants or other military objects" or are "themselves military objectives". Article 2(4) of Protocol III thus addresses the issue of environmental protection directly.

Oeter rightly points out ${ }^{111}$ that Protocol III exceeds the provisions of Additional Protocol I and the ENMOD Convention in so far as the former does not adhere to the

September 2010).

106

107

108

109

110

111

Ibid.

UN Document A/CONF 95/15.

This term is used by UNEP: see, in particular, Mrema et al (2009) at 12.

Ibid.

See, in particular, Art 6(b)(ix) and Art 6(b)(x) of Protocol II of 1980.

See, in particular, Oeter S "Method and means of combat" in D Fleck (ed) The Handbook of 
standards of "widespread, long-standing and severe effects" which the latter two instruments both seem to uphold. Instead, Protocol II would seem to apply where the effects of an armed conflict is "spatial" and "limited", thus possibly limiting the efficacy of Additional Protocol I and the ENMOD Convention in creating a "widereaching duty"112 to secure effective protection for the environment during wartime.

Yet, besides this development, neither the Convention on Conventional Weapons and Protocol III marks any improvement as far as liability for damage to the environment during armed conflict is concerned. The reason is to be found in the fact that no liability regime and/or system of redress for a violation of these two key instruments is established.

As a means to address the absence of a liability regime in Protocol II, an Amended Protocol on Prohibitions or Restrictions on the Use of Mines, Booby-Traps and Other Devices (the Amended Protocol) was adopted in 1996. Article 7(1)(i) and Article $7(1)(j)$ of the Amended Protocol contain similar provisions as Article 6(b)(ix) and Article 6(b)(x) of Protocol II. The Amended Protocol goes further, however, in that it provides that States Parties should "take steps to prevent and suppress violations of the Protocol by persons or on territory under their jurisdiction or control". ${ }^{113}$ On the measures envisaged, Article 14(2) encourages states to impose penal sanctions under their municipal law and thus the Amended Protocol envisages a liability regime which is the duty of States Parties to uphold.

The established liability regime is, however, problematic for two reasons. First, the Amended Protocol only contains provisions on individual (criminal) responsibility. It neither contains provisions on the liability of states for noncompliance nor for any redress for victims of state violations. And secondly, Article 14(1) of the Amended Protocol also fails to establish a mechanism for supervision or for the verification of any violation of its provisions.

The most pertinent aspects of the Chemical Weapons Convention as these relate to the impact of armed conflict on the natural environment will be examined next.

\subsection{The Chemical Weapons Convention}

Although the Chemical Weapons Convention was adopted in January 1993, it only came into force in 1997.114 Chemical substances have both a direct and acute impact

Humanitarian Law in Armed Conflicts (1995) 105 at 117.

112

113

114

This term is suggested by UNEP: see, in particular, Mrema et al (2009) at 12.

See, in particular, Art 14(1) of the Additional Protocol of 1996.

Approved by the United Nations General Assembly on 30 November 1992 and opened for signature on 13 January 1993. The Chemical Weapons Convention remained open for signature until its entry into force on 29 April 1997, 180 days after the deposit of the $65^{\text {th }}$ instrument of ratification by Hungary. The Chemical Weapons Convention augments the Geneva Protocol of 1925 for chemical weapons and includes extensive verification measures such as on-site inspections. It does not, however, cover biological weapons. 
on the (natural) environment ${ }^{115}$ and, for this reason, the Chemical Weapons Convention imposes obligations on States Parties not to develop, produce, transfer, stockpile or retain chemical weapons. In fact, Article 1 specifically prohibits the use of chemical weapons, including assisting, encouraging or inducing anyone to engage in any of the prohibited activities. States Parties are mandated to destroy all chemical weapons owned and abandoned on the territory of another State Party or possessed by them. Article 1(5) furthermore obliges States Parties not to use riot control agents (such as tear gas) as a method of warfare..

In relation to the environment, Articles 4(10), 5(11) and 7(1) of the Chemical Weapons Convention mandate States Parties to ensure the protection of the environment during transportation, sampling, storage, destruction and implementation of all chemical weapons. Article 12 of the Chemical Weapons Convention provides for measures to redress an existing situation and to ensure compliance, including sanctions, and the Conference of the States Parties (the Conference) is empowered to "redress and remedy any situation which contravenes the provisions of the [Chemical Weapons] Convention". 116

Two bodies have been assigned a role to redress a situation that may arise, the Conference and the Executive Council. The Conference, upon recommendation of the Executive Council, may restrict or suspend a State Party's rights and privileges under the Convention. The Conference may also recommend collective measures to States Parties where serious damage to the object and purpose of the Convention results from activities prohibited, such as military use of chemicals for warfare, and these measures must conform to international law. Where a situation is grave, the issue should be brought to the United Nations General Assembly and the Security Council. The Convention thus seeks to guard against the use of chemicals causing damage to the environment, provides a regime of sanctions and also appears to cover non-international armed conflicts as it mandates States Parties to establish both civil and criminal liabilities under international law.

In order to conclude the assessment of relevant provisions contained in international instruments that are specifically aimed at protecting the environment during armed conflict, three further instruments must be considered. These are: the Convention on the Prohibition of the Use, Stockpiling, Production and Transfer of Anti-Personnel Mines and on Their Destruction (the Convention on Anti-Personnel Mines); the Convention on the Prohibition of the Development and Production and Stockpiling of Bacteriological (Biological) and Toxic Weapons and on their Destruction (the Bacteriological Weapons Convention); and the Non-Proliferation of Nuclear Weapons Treaty (the Nuclear Weapons Treaty). Each of these three Conventions will now be considered briefly.

115 See, in general, Mrema et al (2009) at 15.

116 See, in particular, Art 13(19)(k) of the Chemical Weapons Convention of 1993. 


\subsection{The Convention on Anti-Personnel Mines}

The Convention on Anti-Personnel Mines was adopted in 1997 and partly imposes an obligation on States Parties not to use anti-personnel mines in armed conflict and to destroy, or ensure the destruction of, anti-personnel mines. ${ }^{117}$ In carrying out this destruction, States Parties must provide details of environmental implications (in case of a further extension of a previous request for extension of a deadline to destroy $)^{118}$ and the safety and environmental standards observed. The provisions relating to the protection of the environment under the Convention of AntiPersonnel Mines relates to disarmament, yet there is no liability regime established for failure to comply with or to implement its provisions. ${ }^{119}$

\section{The Bacteriological Weapons Convention}

The Bacteriological Weapons Convention of 1972 does not prohibit the use of bacteriological weapons as such, as this is specifically provided for under the Protocol for the Prohibition of the Use in War of Asphyxiating, Poisonous or Other Cases and of Bacteriological Methods of Warfare of 1925. The Bacteriological Weapons Convention extends beyond the latter, however, in one significant respect, namely by prohibiting the degradation of the natural environment. ${ }^{120}$ Complaints must be directed to the Security Council. ${ }^{121}$ And yet, even in the event that the Security Council may decide that there is (or has been) any exposure to danger, there is no liability regime established under the Convention. ${ }^{122}$

\section{The Nuclear Weapons Treaty}

The Nuclear Weapons Treaty of 1968 relates to disarmament, and thus its key objectives relate to the prevention of the proliferation of nuclear weapons. The Nuclear Weapons Convention does not ban the use of nuclear weapons in armed conflict, even though the ICJ has on occasion expressly acknowledged that the use of nuclear weapons would be a "serious danger to future generations" and has the "potential to damage the future environment, food and marine ecosystem", including "genetic defects and illnesses in future generations". ${ }^{123}$ Yet, even so, the ICJ has confirmed that nuclear weapons may be used in self-defence as long as their use

\footnotetext{
117 See, in particular, Art 1(1) and 1(2) of the Convention on Anti-Personnel Mines. See, in particular, Arti 5(4) of the Convention on Anti-Personnel Mines. See, in particular, Art 7(f) of the Convention on Anti-Personnel Mines. See, in particular, Art 2 of the Bacteriological Weapons Convention. See, in particular, Art 6 of the Bacteriological Weapons Convention. See, in particular, Art 7 of the Bacteriological Weapons Convention. Per Koroma J (dissenting) in Advisory Opinion on the Legality of the Threat or Use of Nuclear Weapons 1996 ICJ Reports 226 para 35.
} 
is proportionate to the pursuit of military objectives. ${ }^{124}$ The principle that states may not engage in activities within their territory that cause damage to the environment of other states or to areas beyond the limits of their (national) jurisdiction, has also been confirmed by the ICJ when it declared that

"the existence of the general obligation of states to ensure that activities within their jurisdiction and control respect the environment of other states or of areas beyond national control is now part of the corpus of international law relating to the environment". 125

IHL treaty provisions that indirectly protect the natural environment during armed conflict will be explored next.

\section{IHL TREATY PROVISIONS THAT INDIRECTLY PROTECT THE ENVIRONMENT DURING ARMED CONFLICT}

The rules of IHL treaty law that protect the natural environment indirectly can be subdivided into the following five categories, namely: (a) rules limiting or prohibiting certain weapons and methods of warfare; (b) clauses protecting civilian objects and property; (c) clauses protecting cultural sites; (d) rules pertaining to installations containing dangerous forces; and (e) limitations on certain specifically defined areas. Each of these categories will now be examined.

\section{5 .1 Limitations on means and methods of warfare}

Many weapons that are created have the potential to cause serious and long-lasting damage to the environment. However, by limiting the creation and use of such weapons, it could be argued that such a restriction serves to protect the environment indirectly. UNEP is rightly of the opinion, however, that "very little has been achieved"126 in so far as the enforcement of the law of The Hague ${ }^{127}$ is concerned. Consequently, most instances thus far have pertained to the law of

124 Ibid paras 33 and 34. For an account of the ICRC's understanding of the ICJ's judgment, see Bugnion $\mathrm{F}$ "The International Committee of the Red Cross and nuclear weapons: From Hiroshima to the dawn of the 21 $1^{\text {st }}$ century" 87 No 859 International Review of the Red Cross 511 at 520-523. Ibid para 29.

126 See, in general, Mrema et al (2009) at 14. See also Art 22 of the Fourth Hague Convention which expressly states that "the right of belligerents to adopt means of injuring the enemy is not unlimited". UNEP rightly points out that Art 22 of the Fourth Hague Convention is regarded as "one of the most significant provisions in the regulations in so far as a precautionary imperative can be implied from it in the absence of explicit provisions": Ibid 10 at 14.

127 Notably the Fourth Hague Convention respecting the Laws and Customs of War on Land of 1907. 
Geneva $^{128}$ which is intended to protect certain categories of persons, including civilian persons and civilian objects.

\subsection{Protection of civilian objects and property}

UNEP rightly argues that the various measures that relate to the protection of civilian objects and civilian property "could provide a more effective legal basis for protecting the environment during armed conflict than those protecting the environment per $s e^{\prime \prime}{ }^{129}$ However, these provisions would only find application under existing IHL treaty law. ${ }^{130}$ To this end, the Fourth Geneva Convention, ${ }^{131}$ which pertains to the treatment of civilian persons and property, declares noncombatants "protected persons" whose lives and livelihoods shall be kept safe during an armed conflict by any Party to the conflict or, in the event of an occupation, by the Occupying Power. ${ }^{132}$ Article 147 expressly includes the "extensive destruction and appropriation of property not justified by military necessity and carried out unlawfully and wantonly" among the acts constituting grave breaches of the Fourth Geneva Convention. ${ }^{133}$

\subsection{Protection of cultural objects and property}

The Hague Convention for the Protection of Cultural Property in the Event of Armed Conflict (the Hague Convention on Cultural Property) of $1954^{134}$ and its Protocols seek to accord enhanced protection to civilian objects during armed conflict. Article 1 (a) defines cultural property as

128 Notably persons who do not, or who no longer, directly participate in the hostilities: see, in particular, the four Geneva Conventions of 1949 and their two Additional Protocols of 1977. Emphasis added. See, in particular, Mrema et al (2009) at 16.

Such as The Hague Regulations attached to the Fourth Hague Convention of 1907 which stipulate that it is forbidden "to destroy or seize the enemy's property, unless such destruction or seizure be imperatively demanded by the necessities of war". In addition, the "enemy property" could include protected areas and environmental resources which would, as such, be indirectly protected by the Hague Regulations. The Geneva Convention Relative to the Protection of Civilian Persons in Time of War of 1949.

Art 4 of the Fourth Geneva Convention of 1949 defines protected persons as "those who, at a given moment and in any manner whatsoever, find themselves, in case of a conflict or occupation, in the hands of a Party to the conflict or Occupying Power of which they are not nationals".

133 See Art 147 of the Fourth Geneva Convention of 1949. Furthermore, in the context of occupation, see Article 53 which states that "any destruction by the Occupying Power of real or personal property belonging to the individual or collectively to individuals, or to the State, or to other public authorities, or to social or cooperative organizations, is prohibited, except where such destruction is rendered absolutely necessary by military operations".

Adopted in The Hague, Netherlands, on 14 May 1954 and entered into force on 7 August 1956. 
"movable or immovable property of great importance to the cultural heritage of every people, such as monuments of architecture, art or history, whether religious or secular; archaeological sites; groups of buildings which, as a whole, are of historical or artistic interest; works of art; manuscripts, books and other objects of artistic, historical or archaeological interest; as well as scientific collections and important collections of books or archives or of reproductions of the property defined above".

Cultural property would also include "buildings whose main and effective purpose is to preserve or exhibit"135 movable cultural property such as museums, large libraries and depositories of archives, including refuges intended to shelter, in the event of armed conflict, the movable cultural property. Centres "containing a large amount of cultural property" would also be included under this definition. ${ }^{136}$

In essence, the Hague Convention on Cultural Property provides for the protection, ${ }^{137}$ safeguard ${ }^{138}$ and respect ${ }^{139}$ for cultural property. To achieve these objectives, there are several provisions relating to the grant of special protection for the purpose of sheltering movable property, ${ }^{140}$ immunity of cultural property under special circumstances, ${ }^{141}$ transport $^{142}$ and the creation and use of a distinctive emblem. ${ }^{143}$ The Convention expressly applies to international armed conflicts and to cases of occupation of territories, ${ }^{144}$ and Article 28 allows States Parties to "prosecute and impose penal or disciplinary sanctions" on "persons who commit or order" breaches of its provisions. The provision relating to liability only concerns individual responsibility; there is no liability regime for violations perpetrated by States Parties. And, since the Convention does not apply to non-international armed conflicts, the liability regime consequently only relates to violations of its provisions committed by individuals during an international armed conflict.

The Regulations for the Execution of the Convention for the Protection of Cultural Property in the Event of Armed Conflict (the Regulations) provide under Article 5 that the Protective Powers, established under Article 21 of the Convention, should investigate violations. Article 6 of the Regulations burdens the Commissioner General with this responsibility. And yet there exists no regime of sanctions for violations; the Regulations only create powers of investigation into any violations.

The First Hague Protocol for the Protection of Cultural Property in the Event of Armed Conflict (the First Hague Protocol) of 1954, which only applies to

See, in particular, Article 1(b) of the Hague Convention on Cultural Property. See, in particular, Article 1(c) of the Hague Convention on Cultural Property. See, in particular, Article 2 of the Hague Convention on Cultural Property. See, in particular, Article 3 of the Hague Convention on Cultural Property. See, in particular, Article 4 of the Hague Convention on Cultural Property. See, in particular, Art 8 of the Hague Convention on Cultural Property of 1954. See, in particular, Art 9 of the Hague Convention on Cultural Property.

See, in particular, Arts 12,13 and 14 of the Hague Convention on Cultural Property.

See, in particular, Arts 16 and 17 of the Hague Convention on Cultural Property. See, in particular, Art 18 of the Hague Convention on Cultural Property. 
international armed conflicts, ${ }^{145}$ prohibits the export and sale of cultural property from an occupied territory. ${ }^{146}$ Yet, unlike the Hague Convention on Cultural Property, the First Hague Protocol fails to provide for any liability in case of a breach of its provisions.

To remedy the deficiencies of both The Hague Convention on Cultural Property and the First Hague Protocol in the former Yugoslavia, the Second Hague Protocol for the Protection of Cultural Property in the Event of Armed Conflict (the Second Hague Protocol) was adopted in 1999.147 Not surprisingly, the Second Hague Protocol seeks to widen the scope of protection accorded to cultural property. To this end, Articles 3 and 22 of the Second Hague Protocol extend the protection of cultural property to non-international armed conflicts. ${ }^{148}$

Chapter 4 of the Second Hague Protocol introduces a liability regime which covers individual criminal responsibility ${ }^{149}$ and which both adopts the principle of universality and provides for the extradition of offenders. ${ }^{150}$ Articles 15(1) and 21 expressly include offences such as attacks on protected cultural property and the misuse of cultural property, and thus remedy the First Hague Protocol by creating both an offence and express liability for the illicit export, removal and transfer from an occupied territory of cultural property. ${ }^{151}$ Of particular significance is Article 15(2) which provides for the sanction of domestic criminalisation and extends responsibility against persons other than those who directly committed the

.

$$
\text { (c) }
$$
whatsoever and without undue delay, the case to its competent authorities, for the purpose of prosecution, through proceedings in accordance with its domestic law or with, if applicable, the relevant rules of international law".

151 See Art 15(1) of the Second Hague Protocol which reads: "1. Any person commits an offence within the meaning of this Protocol if that person intentionally and in violation of the Convention or this Protocol commits any of the following acts: a. making cultural property under enhanced protection the object of attack; b. using cultural property under enhanced protection or its immediate surroundings in support of military action; c. extensive destruction or appropriation of cultural property protected under the Convention and this Protocol; d. making cultural property protected under the Convention and this Protocol the object of attack; e. theft, pillage or misappropriation of, or acts of vandalism directed against cultural property protected under the Convention". 
proscribed act or acts. The Second Hague Protocol also allows for state responsibility and repatriation under Article 38, albeit that no sanctions for a violation of state responsibility are provided. There is also no mechanism provided for the enforcement of state responsibility.

On the whole, the Second Hague Protocol thus provides a somewhat improved regime of protection compared to that which preceded it. Not only does the Second Hague Protocol clarify the particular measures of precaution to be implemented, but it also articulates more clearly the types of conduct that would lead to criminal sanctions and insists that States Parties exercise jurisdiction over such violations. ${ }^{152}$ In addition, the Second Hague Protocol extends the Hague Convention on Cultural Property's protection to non-international armed conflicts. ${ }^{153}$ It furthermore introduces innovative concepts that could serve to significantly enhance the protection of all natural resources in wartime, to the degree that these could be conceptualised as cultural property in terms of Article 1 of the Hague Convention on Cultural Property. ${ }^{154}$

\subsection{Protection of industrial installations containing dangerous forces}

Article 56 of Additional Protocol I proscribes "works or installations containing dangerous forces" including "dams, dykes and nuclear electrical generating stations" as objects of attack, even though these objects may be military objectives. ${ }^{155}$ Yet it is noticeable that oil fields and petrochemical plants are not, for example, explicitly mentioned and may, according to UNEP, "have been intentionally excluded". ${ }^{156}$ The result of this exclusion means that Article 56 did not cover the attacks by Iraq on the Kuwaiti oil fields during the first Gulf War. ${ }^{157}$ In addition, the only meaningful extension provided for by Additional Protocol II is to be found in Article 15, extending the categories of protection contained in Article 56 of Additional Protocol I to non-international armed conflicts and thus securing protection for dykes, dams and nuclear electrical generating stations against being targeted in internal armed conflict situations. There appears to be general agreement, however, that Article 56 does not constitute customary IHL. ${ }^{158}$

152 See, in general, Mrema et al (2009) at 18.

153 See, in particular, Art 22(1) of the Second Hague Protocol of 1999 which contains an express reference to non-international armed conflicts and reads: "1. This Protocol shall apply in the event of an armed conflict not of an international character, occurring within the territory of one of the Parties".

See, in general, Mrema et al (2009) at 18.

See, in particular, Art 56(1) of Additional Protocol I. conflict were covered by Art 56 of Additional Protocol I. 


\subsection{Limitations based on targeted areas}

The limitations based on targeted areas can be subdivided into three categories: (a) territories under occupation; (b) neutral territories; and (c) demilitarised zones. The Hague Regulations were the first to articulate the rules applicable to occupied territories. To this end, Article 55 of the Fourth Hague Convention spells out the rules of ususfructus for the Occupying Power. Article 55 expressly provides that the Occupying Power must exercise its right of use over the occupied property in such a manner that it does not cause damage or destruction to it. An exception is, however, made in the case of military necessity. Furthermore, Article 53 of the Fourth Geneva Convention lists as expressly prohibited "any destruction by the Occupying Power of real or personal property belonging individually or collectively to private persons" in occupied territories, "except where such destruction is rendered absolutely necessary by military operations". 159

Even though the rules applicable to neutral territories emanate from customary IHL, these rules too were largely codified in The Hague Conventions. ${ }^{160}$ The idea of neutral territories is based on essentially two requirements, namely the "duty of abstention and impartiality" and secondly, that the "relations between belligerents and neutrals" are to be governed by the "law applicable in times of peace". ${ }^{161}$

Areas that are formally proposed by any party to the conflict as "demilitarised" zones can be established by way of a written agreement between the parties "in the regions where fighting is taking place". ${ }^{162}$ The express object of such "demilitarised" zones is "to shelter from the effects of war" persons who do not (or who no longer) take an active part in the hostilities. Any violation of the written agreement will constitute a grave breach of IHL. Areas like Antarctica and outer space are also specifically protected by way of treaties from the impact of armed conflict. ${ }^{163}$

159 According to UNEP, the special status of occupied territories and the accompanying legal regime "may offer some guiding principles for dealing with similar situations in the context of noninternational armed conflict". The damage caused to the natural environment and valuable resources is often directly due to the fact that such activities "finance armed forces and their weaponry": see, in particular, Mrema et al (2009) at 19.

160 See, in particular, The Hague Convention V and The Hague Convention XIII of 1907. UNEP is rightly of the opinion that the "more recent treaties have not added to this codification, other than a few details": see Mrema et al (2009) at 19.

161 Ibid. With respect to the environment, this customary law principle is articulated in Article II(5) ("General Principles of International Law") of the ICRC Guidelines for Military Manuals and Instructions on the Protection of the Environment in Times of Armed Conflict, where it is stipulated that "obligations relating to the protection of the environment towards States not party to an armed conflict (e.g. neighbouring States) and in relation to areas beyond the limits of national jurisdiction (e.g. the High Seas) are not affected by the existence of the armed conflict to the extent that they are not inconsistent with the applicable law of armed conflict". See also, in general, Gasser (1996) at 230-237.

162 See, in particular, Art 15 of the Fourth Geneva Convention and Art 60 of Additional Protocol I.

163 See, in particular, the Antarctic Treaty of 1959 and the Treaty on Principles Governing the Activities of States in the Exploration and Use of Outer Space, Including the Moon and Other 


\section{ENFORCEMENT AND IMPLEMENTATION}

\subsection{Existing machinery}

The treaties of IHL provide various mechanisms for implementing their substantive provisions. Included among these are: (a) the IHL regime of Protecting Powers; (b) the International Fact-Finding Commission; (c) specific functions designated to the ICRC pertaining to the interpretation and monitoring of the implementation of IHL; (d) the general obligation to "ensure respect for" IHL; (e) the principle of individual criminal responsibility; and (f) the obligation to ensure that the provisions of the four Geneva Conventions and Additional Protocols are disseminated widely by states.

The existing machinery governing enforcement and implementation is primarily concerned with issues of state responsibility. The system of Protecting Powers is governed under the four Geneva Conventions and their Additional Protocols, and, in essence, require that Protecting Powers must both attend to the implementation of the provisions of these international instruments and "safeguard the interests of the parties to a conflict and their nationals on enemy territory". ${ }^{164}$

Article 90 of Additional Protocol I provides for the establishment of an International Fact-Finding Commission (the Commission) equipped with the authority to investigate serious violations and grave breaches of the four Geneva Conventions and their Additional Protocols. The functions of the Commission are of a facilitative nature, conducted through its offices, and would include the restoration of respect for the four Geneva Conventions and its Additional Protocols. ${ }^{165}$ The Commission's competence depends on a special declaration of acceptance ${ }^{166}$ and struggled initially to garner sufficient state support. Although the Commission was eventually constituted in 1991 with receipt of the twenty-ninth state declaration, it has never been utilised largely due to a lack of support from States Parties. ${ }^{167}$

As a neutral and independent humanitarian institution, the ICRC's mission is to provide assistance and protection to certain categories of persons during armed conflict. The ICRC's various mandates are defined in the four Geneva Conventions and the ICRC may thus "find itself acting as a substitute for Protecting Powers". 168 The ICRC also has a recognised right of initiative that assigns to it a role in monitoring the implementation of IHL.

Celestial Bodies of 1987.

See, in particular, Bouvier ICRC Report 1992 para 6.1.

See, in general, Reyhani (2007) at 338.

The special declaration of acceptance is provided for in terms of Art 90(2)(c) of Additional Protocol I.

See, in general, Reyhani (2007) at 338 n 57.

See, in particular, Bouvier ICRC Report 1992 para 6.3. 
Article 1 common to the four Geneva Conventions and to Additional Protocol I stipulates that the Contracting States are under an obligation to "respect and to ensure respect for" these key IHL instruments "in all circumstances". Common Article 1 thus reiterates the obligation of all States Parties to make sure that humanitarian commitments are met by each and every State Party and, in particular, when engaged in an armed conflict. ${ }^{169}$ It goes without saying that the duty to protect the natural environment in wartime constitutes such a fundamental humanitarian obligation. Therefore, by relying on the clause of si omnes, any third state could be said to have an interest in damage caused to the natural environment for the duration as well as beyond the termination of an armed conflict and could, in principle, invoke the appropriate judicial machinery that exists under the United Nations, notably the ICJ. ${ }^{170}$

The possibility of individual criminal responsibility has existed under IHL long before the adoption of the Rome Statute of the ICC, albeit at the domestic level. States Parties to the four Geneva Conventions and their Additional Protocols "are required to take all possible measures to ensure that their obligations are properly discharged in time of war". ${ }^{171}$ One of the most significant of these measures is the adoption of criminal sanctions at the national level. ${ }^{172}$ In this context, Article 147 of the Fourth Geneva Convention is of particular significance as it clearly establishes the unjustified destruction of property as a war crime, and although causing widespread, long-term and severe damage to the environment is not, as such, a grave breach of Additional Protocol I, it may be part of grave breaches of other provisions. ${ }^{173}$

Finally, each State Party to the four Geneva Conventions and their Additional Protocols must ensure that the text of these instruments is disseminated as widely as possible throughout its territory in both peacetime and wartime. States Parties must, inter alia, incorporate the study of the subject into their programmes of military and, if possible, civilian instruction.

\subsection{Individual criminal responsibility: the Rome Statute}

Article 8(2)(b)(iv) of the Rome Statute of the ICC expressly includes as a war crime

"intentionally launching an attack in the knowledge that such attack will cause incidental loss of life or injury to civilians or damage to civilian objects or widespread, long-term and

\footnotetext{
169 Ibid para 6.4.

170 See, in general, Reyhani (2007) at 339.

171 See, in particular, Bouvier ICRC Report 1992 para 6.5.

172 Ibid.

173 Ibid.
} 
severe damage to the natural environment which would be clearly excessive in relation to concrete and direct overall military advantage anticipated". ${ }^{174}$

Although this formulation is, for the most part, based on Article 35(3) of Additional Protocol I, ${ }^{175}$ Dinstein rightly points out that the Rome Statute contains two significant alterations:

"(i) the Statute requires both intention and knowledge of the outcome, rather than either intention or expectation as set forth in the Protocol I; and (ii) for the war crime to crystallize, the damage to the natural environment must be clearly excessive in relation to the military advantage anticipated". 176

Dinstein explains that the first alteration is necessitated by the conception of the act as a war crime which will establish "individual criminal responsibility and liability", and thus "only an individual acting with both knowledge and intent would have the necessary mens rea exposing him to penal sanctions". ${ }^{177}$ Yet this requirement, coupled with the prohibition of subjectivity, could place a heavy evidentiary burden on the prosecution. ${ }^{178}$ The possible application of the provisions of the Rome Statute may thus be hampered by the fact that both intention and knowledge of the outcome is required, instead of either intention or expectation as is the case in Additional Protocol I.

The second alteration, according to Dinstein, is derived from the "amalgamation in one paragraph of the materiae of the protection of civilians (or civilian objects) and that of the natural environment", and so a "balance must be struck between the military advantage anticipated" and "any incidental injury to civilians or civilian objects". ${ }^{179}$

Liability under the Rome Statute thus relates to a specific intention which is different from the intention and foreseeability ("intended, or may be expected") test contained in Article 35(3) of Additional Protocol I. In this regard the Rome Statute also differs from the ENMOD Convention, as Article 8(2)(b)(iv) clearly requires that all three thresholds must be met simultaneously and, as a consequence, the Rome

Emphasis added. For a detailed discussion of the Elements of Crimes under the Rome Statute, see Dörmann K, Doswald-Beck L and Kolb R Elements of War Crimes under the Rome Statute of the International Criminal Court: Sources and commentary (2003) at 161-176.

Ibid 161 at 166. Art 8(2)(b)(iv) of the Rome Statute, in fact, contains traces of Arts 35(3), 51(5) and 51(5) as well as of Arts 55(1), 83(3)(b) and 85(3)(b) of Additional Protocol I: see, in particular, Werle G Principles of International Criminal Law (2005) at 350 para 1041. See also, in general, Schabas WA The International Criminal Court: A Commentary on the Rome Statute (2010) at 231-232.

Dinstein (2001) at 535.

Ibid at 536. See also, in general, Werle (2005) at 352 para 1047.

Ibid 267 at 351 para 1044.

Ibid 523 at 536. Emphasis added. Dinstein explains that this would include the natural environment (as a civilian object), unless part of the environment, such as a forest, "is deemed a military objective in the circumstances prevailing at the time": see, in particular, Dinstein (2001) at 536. 
Statute may well experience the same difficulty as Additional Protocol I in that it may prove challenging to satisfy the cumulative threshold test. ${ }^{180}$ It furthermore appears that while the provisions of the Rome Statute would cover situations such as Iraq's intentional damage to the Kuwaiti oil wells, its liability regime can only apply to natural persons and not to states. ${ }^{181}$

It is to be welcomed, however, that the war crimes provisions contained under Article 8 of the Rome Statute would apply equally to both international and noninternational armed conflicts. ${ }^{182}$ Any intentional attack by an individual on the natural environment which meets the criteria set out in Article 8(2)(b)(iv) would accordingly be punishable as a war crime under the Rome Statute, irrespective of whether such an act was committed during an international armed conflict or during the course of a non-international armed conflict.

\subsection{Dissemination and national implementation}

Arguably, the most effective means of addressing the protection of the natural environment during armed conflict is through the national implementation of such rules. Non-governmental organisations that have international standing, such as the International Committee of the Red Cross (the ICRC), have drafted proposals for the implementation of existing rules of IHL to be incorporated into the military manuals of the armed forces. ${ }^{183}$ The Guidelines for Military Manuals and Instructions on the Protection of the Environment in Times of Armed Conflict (the Guidelines) proposed by the ICRC were submitted to the United Nations General Assembly in 1994. Without formally approving the Guidelines, the General Assembly invited all states to "give due consideration to the possibility of incorporating them into their military manuals and other instructions addressed to their military personnel". ${ }^{184}$

See also, in general, Reyhani (2007) at 340 and Dinstein (2001) at 535-536.

See, in general, Dörmann et al (2003) at 176. See also Nanda VP "International environmental norms applicable to nuclear activities with particular focus on decision of international tribunals and international settlements" available at http://www.law.du.edu/ documents/djilp/International-Environmental-Norms-Applicable-to-Nuclear-Activites.pdf (accessed 2 September 2010).

Art 8 of the Rome Statute conceives of war crimes as acts which can be committed within the context of both international and non-international armed conflicts: see, in particular, Art 8(2)(c) ("Violations of common Article 3 of the 1949 Geneva Conventions") as well as 8(2)(e) ("Other serious violations of the laws and customs applicable in armed conflicts not of an international character") of the Rome Statute. See also, in general, Werle (2005) at 352 para 1048. But compare Schabas (2010) at 232 n 260.

183 See, in particular, Resolution 1 adopted by the $26^{\text {th }}$ International Conference of the Red Cross and Red Crescent in Geneva, Switzerland, in 1995. The Resolution inter alia urged the ICRC, the International Federation of Red Cross and Red Crescent Societies and the National Red Cross and Red Crescent Societies to "contribute to the effort for achieving better implementation of international humanitarian law, the main objective being to prevent violations from occurring": see, in particular, Gasser (1996) at 230.

See GA res 49/50 of 9 December 1994. The Guidelines have been published as an annex to the 
The Guidelines are intended as a mere "tool"185 to facilitate the instruction of armed forces. In essence, the Guidelines consist of a summary of the existing applicable rules of IHL which must both be known and respected by members of the armed forces, and thus their aim is to "contribute in a practical and effective way to raising awareness" of the natural environment in time of armed conflict. ${ }^{186}$ In turn, Green Cross International has explained the dangers the natural environment is exposed to during armed conflict and has rightly motivated that a culture of compliance, coupled with IHL, is the appropriate way to proceed. ${ }^{187}$

However, it is self-evident that a change in the attitudes of states towards the natural environment would be far more effective than any ex post facto condemnation, political pressure and, in the final instance, prosecution of violations. Yet for the Guidelines to serve their purpose an update will be required, coupled with their subsequent consideration by the General Assembly for adoption. UNEP rightly advocates the latter, due to the "rapid transformations in the methods and means of warfare" 188 as well as the marked proliferation of non-international armed conflicts, especially on the African continent. Viewed in such a context, the Guidelines should thus ideally also explain fundamental concepts contained in Additional Protocol I, consider the precise relationship between the Rome Statute and IHL, examine the scope of possible application of IEL during armed conflict, and explore, in sufficient detail, the protection accorded to the environment during noninternational armed conflicts. ${ }^{189}$

\subsection{The quandary of non-international armed conflicts}

The rules pertaining to non-international armed conflict are less developed than those specifically regulating international armed conflicts. ${ }^{190}$ Article 3 common to the four Geneva Conventions is, for example, silent on protecting the environment during civil wars and only addresses humanitarian concerns in the most basic sense. Additional Protocol II likewise contains no provisions relating directly to the environment. However, Article 14 which concerns the protection of objects indispensable to the survival of the civilian population has a direct impact on the environment, proscribing attacks on agricultural areas, irrigation works, foodstuffs and drinking water installations and supplies. The same applies to Article 15 which protects "works and installations containing dangerous forces". Bouvier rightly points out, however, that other legal provisions pertaining to the environment, such

United Nations Secretary-General's Report of 19 August 1994: see UN Doc A/49/323 (1994).

This term is employed by Gasser: see Gasser (1995) at 641.

See, in particular, Gasser (1996) at 231.

Ibid.

See, in particular, Mrema et al (2009) at 5.

Ibid.

See, in general, Bouvier ICRC Report 1992 para 5. 
as those contained in international treaties, are likely to remain enforceable against a state in which there exists a non-international armed conflict.191

Due to the fact that only a small number of states had ratified Additional Protocol II by the late 1980s, this instrument could not be applied in respect of the noninternational armed conflicts in, for example, Angola, Haiti, Somalia and Sri Lanka. ${ }^{192}$ The general principles of IHL and customary law could, therefore, be used effectively to apply to situations not expressly provided for in the case of noninternational armed conflicts, as there is no specific treaty norm that explicitly addresses the issue of environmental damage during non-international armed conflicts.

\subsection{Customary IHL}

The rules, principles and norms of IHL will have acquired the status of custom when they enjoy "general or widespread"193 application. And since the four principles of distinction, military necessity, proportionality and humanity could well be said to enjoy such a level of application, UNEP rightly argues that these fundamental principles would "complement and underpin the various IHL instruments and apply to all states". 194 UNEP also correctly suggests that the grave breaches provisions (this is unfortunately a standard phrase used in IHL) contained in the four Geneva Conventions and in Additional Protocol I would enjoy the status of customary IHL, 195 albeit that the causing of "widespread, long-term and severe damage to the environment"196 is not expressly mentioned.

Other provisions contained in the four Geneva Conventions and in Additional Protocol I could be interpreted as providing protection to the natural environment during armed conflict. Specific examples include Article 50 of the First Geneva Convention which expressly refers to "extensive destruction of property, not justified by military necessity and carried out unlawfully and wantonly"197 and Article 85(3)(b) of Additional Protocol I which prohibits the "launching [of] an indiscriminate attack affecting civilian objects in the knowledge that such attack will cause excessive damage to . . . civilian objects". ${ }^{198}$

191 Ibid.

192 See, in general, Mrema et al (2009) at 28.

193 See, in particular, Dugard (2005) at 32.

194 Except, of course, to those states who persistently object to these four key principles of IHL: Mrema et al (2009) $20 \mathrm{n} \mathrm{59.} \mathrm{For} \mathrm{more} \mathrm{on} \mathrm{the} \mathrm{consequences} \mathrm{of} \mathrm{a} \mathrm{persistent} \mathrm{objector} \mathrm{in}$ international law, see Dugard (2005) at 32. Ibid at 28.

196 See, in particular, Art 147 of the Fourth Geneva Convention and Art 85 of Additional Protocol I.

197 See in this regard also Art 51 of the Second Geneva Convention and Art 147 of the Fourth Geneva Convention.

198 See, in particular, Art 85(3)(b) of Additional Protocol I. See also Art 85(3)(c) which prohibits "launching an attack against works or installations containing dangerous forces in the 
Although the four Geneva Conventions enjoy universal ratification, the situation is less promising as far as Additional Protocols I and II are concerned. The United States has, for example, raised particular objections to Additional Protocol I and has hitherto failed to ratify Additional Protocol II. ${ }^{199}$ It is therefore to be welcomed that the ICRC has identified three Rules in their Study on Customary International Law, published in $2005^{200}$ that could secure enhanced protection for the natural environment in wartime. To this end, Rule 43 states that the "general principles of the conduct of hostilities apply to the natural environment". ${ }^{201}$ And while Rule 44 stipulates that "methods and means of warfare must be employed with due regard to the protection and preservation of the natural environment", 202 Rule 45 expressly states that the "use of methods or means of warfare that are intended, or may be expected, to cause widespread, long-term and severe damage to the natural environment is prohibited". ${ }^{203}$

The value of the three Rules relate to the fact that they squarely place the fundamental principles of IHL, as these relate to the natural environment, within the context of customary IHL. The difference in applicability of these three Rules in international as opposed to non-international armed conflicts remains open to interpretation, however. ${ }^{204}$

\subsection{General statements}

A further category of protection for the natural environment can be found in general statements issued at, for example, international conferences. ${ }^{205}$ Principle 21 of the Stockholm Declaration of the United Nations Conference on the Human Environment of $1972^{206}$ and Principle 2 of the Rio Declaration on Environment and Development (the Rio Declaration) of $1992^{207}$ both express the concern that states

knowledge that such attack will cause excessive loss of life, injury to civilians or damage to civilian objects".

199 See, in particular, Solis (2010) at 123.

200 See Henckaerts \& Doswald-Beck L Vols I, II and III (2005). Some states and commentators have, however, questioned the expansiveness of the ICRC assessment regarding what constitutes customary IHL.

201 See Henckaerts \& Doswald-Beck Vol I (2005) at 143-146.

202 Ibid 147-151. For a basic discussion of Rule 44 in relation to Additional Protocol I, see Hulme (2010) at 684-687 and Bothe et al (2010) at 574-575. Ibid 151-158. See Mrema et al (2009) at 21. See, in general, Bothe et al (2010) at 584.

206 Stockholm Declaration of the United Nations Conference on the Human Environment (1972) 11 International Legal Materials 1415.

207 Rio Declaration on Environment and Development UN Doc A/CONF151/5/Rev1, (1992) 31 International Legal Materials 874. A recommendation by the Governing Council of UNEP issued in May 1991 proposed that action be taken to prohibit weapons that "cause particularly serious effects on the environment": see UNEP Governing Council 16 ${ }^{\text {th }}$ Session Resolution 16/11 on 
have an obligation "to ensure that the activities that fall within their jurisdiction or control do not cause damage to the natural environment of other States or areas beyond the limits of national jurisdiction".

Principle 23 of the Rio Declaration furthermore states that the "environment and natural resources of people under oppression, domination and occupation shall be protected". And Principle 24 of the Rio Declaration, in turn, declares that

"warfare is inherently destructive of sustainable development. States shall therefore respect international law providing protection for the environment in times of armed conflict and co-operate in its further development, as necessary".

Reyhani rightly argues that these statements provide a challenge to those states "willing to embrace them". ${ }^{208}$ Consequently, the principles articulated in the Stockholm and Rio Declarations are often relied upon to ensure greater compliance with various (peacetime) environmental rules during wartime.

\section{CONCLUDING OBSERVATIONS}

This article sought to establish the effectiveness of the various provisions of international law relating to the protection of the natural environment during armed conflict as these can be divided into general principles, specific provisions as well as provisions that can be considered to provide indirect protection to the environment. In particular, the regime of liability for environmental damage in armed conflict under each of the three categories was examined critically.

It was shown that, apart from the Chemical Weapons Convention, all other treaties dealing specifically with the means and methods of warfare revealed serious inadequacies and that some, such as the Convention on Conventional Weapons and its Protocols, establish no liability regime whatsoever. International instruments that do contain a liability regime, however, reveal serious flaws, to the degree that not all categories of armed conflict are addressed and only criminal sanctions (with no civil liability) are envisaged, coupled with failure to extend liability to States Parties. Some international instruments even fail to provide adequate mechanisms for legal redress or, in instances where such redress is provided, the mechanisms are flawed.

There also exists a glaring lack of case law pertaining to the protection of the environment during armed conflict, and UNEP highlights the unfortunate reality that "in the few instances where judgments were handed down, procedural rather than merit-based reasoning has predominated". ${ }^{209}$ The lack of case law addressing

Military Conflicts and the Environment (31 May 1991), UN Doc A/46/25 (1991). This recommendation led directly to the United Nations Conference on Environment and Development held in Rio de Janeiro, Brazil, in June 1992.

See, in particular, Reyhani (2007) at 237.

209 For examples of these instances, see Mrema et al (2009) at 24-28. 
the responsibility and liability of state violations of IHL may thus well create the precarious impression that there exists some "reluctance in enforcing the applicable law" 210 at the international level.

And yet the protection of the natural environment has gained considerable prominence in the last two decades and many states and (international) organisations have endeavoured to support efforts calling for the adequate protection of this valuable asset during armed conflict. It is self-evident that a balance must be struck between the reality of military necessity and the need to ensure the survival of populations and all forms of life that have been entrusted to mankind. Dinstein rightly laments that customary international law has not yet developed to the degree that both adequate and comprehensive protection is afforded to protecting of the environment during wartime. ${ }^{211}$

Even though treaty law has become increasingly more aware of the plight of the natural environment during armed conflict, Dinstein justifiably cautions that the threshold set by Additional Protocol I could well be said to be too high (especially where durability of the environmental damage is concerned) and that the ENMOD Convention lends itself to a rather restrictive interpretation. ${ }^{212}$ Furthermore, some intentional and direct damage to the environment is not covered by either the ENMOD Convention or Additional Protocol I and, therefore, damage is still, at least in so far as these two instruments are concerned, permissible. ${ }^{213}$ The question thus arises as to how the discrepancies inherent to, for example, Additional Protocol I, the ENMOD Convention and the Rome Statute can be harmonised.

The introduction of numerous international instruments must perhaps be viewed as a starting point in providing the limitations of (unavoidable) destruction caused to the natural environment during armed conflict. Yet if the international community is serious about protecting the environment, individuals and organs of state must actively ensure dedication to, and compliance with, the jus in bello exclusively applicable during armed conflict. This means that all parties to an armed conflict must honour their obligations in terms of existing instruments that are directly or indirectly relevant to the protection of the natural environment in armed conflict, ${ }^{214}$ irrespective of whether they are States Parties or whether the applicable provisions of these instruments may have acquired the status of customary law, bearing in mind also that the rules of general (peacetime) law protecting the natural environment do, in fact, remain in force during armed conflict. ${ }^{215}$

210 Ibid.

211 See Dinstein (2001) at 549.

212 Ibid.

213 Ibid.

214 This position has found strong support at the Conference of Experts on the Use of the Environment as a Tool of Conventional Warfare convened by the Canadian Ministry of External Affairs from 9-12 July 1992 in Ottawa, Canada: see Gasser (1995) at 639 n 13.

215 The continued applicability in armed conflict of important sections of the general international 
Perhaps the most durable answer is to be found in the adoption of an entirely new convention expressly intended to address all situations of environmental damage caused during (or as a consequence of) armed conflict. Birnie, Boyle and Redgwell rightly point out that the law of armed conflict could be regarded as one of the "least sophisticated" branches of "contemporary international law" in that it lacks an "institutional structure for supervision of compliance", and that it thus "relies mainly on the good faith of the parties to a conflict for implementation and application". ${ }^{216}$ Such a convention should thus ideally set a lower threshold for damage caused to the natural environment and establish a redress mechanism for States Parties. Furthermore, an effective judicial system should be established under such a convention to consider issues of liability and redress. This makes sense, as issues of impartiality and guarantees of integrity are significant factors at the level of international adjudication. ${ }^{217}$ Under such a convention the Security Council could serve as the enforcer of judgments as it is already equipped to exercise this duty in terms of Article 94(2) of the United Nations Charter. ${ }^{218}$ Should legitimate fears exist about the ability of the Security Council to ensure the effective implementation of judgments, ${ }^{219}$ a system similar to the one established within the context of the European Court of Human Rights may well be considered. In the latter instance, judgments are implemented with the aid of a Committee of Ministers which facilitates the effective implementation of judgments handed down by the European Court of Human Rights. 220

rules protecting the natural environment was stressed by the International Council of Environmental Law in December 1991 in Munich, Germany: see, in particular, International Council of Environmental Law and IUCN-Commission on Environmental Law "Law concerning the protection of the environment in times of armed conflict" Consultation 13-15 December 1991 Final Recommendations, cited in Gasser (1995) at 639 n 14.

216 See, in general, Birnie P, Boyle A and Redgwell C International Law and the Environment 3ed (2009) at 207. A proposal on the drafting of a "Fifth Geneva Convention on the protection of the environment in time of armed conflict" was indeed discussed at a conference in London in 1992: see Gasser (1995) at $639 \mathrm{n} \mathrm{12.} \mathrm{While} \mathrm{this} \mathrm{approach} \mathrm{was} \mathrm{useful} \mathrm{in} \mathrm{clarifying} \mathrm{issues,} \mathrm{the} \mathrm{suggested}$ solution did not at the time encounter strong support.

Ibid 258.

Art 94(2) of the UN Charter reads: "2. If any party to a case fails to perform the obligations incumbent upon it under a judgment rendered by the [International] Court [of Justice], the other party may have recourse to the Security Council, which may, if it deems necessary, make recommendations or decide upon measures to be taken to give effect to the judgment".

Such a fear may well exist where judgments are made against a permanent member of the United Nations Security Council. In the Case of the Military and Paramilitary Activities in and against Nicaragua (Nicaragua $v$ US) (Merits) 1986 ICJ Reports 14, one could possibly attribute the failure of the Security Council to act to the fact that Art 94(2) of the UN Charter neither mandates the Security Council to enforce judgments nor establishes a procedure whereby such judgments relate to a (permanent) member of the Security Council.

Art 46 para 2 of the European Convention on Human Rights stipulates that the Committee of Ministers (the Committee) is responsible for overseeing the execution of the judgments of the European Court of Human Rights. After final judgment, the Committee invites the respondent state to report on the specific steps as well as any general measures taken in compliance with the state's legal obligation to abide by the judgment. The Committee is assisted by its own 
A new convention should furthermore extend its regime of liability to both states and individuals, thereby capturing the somewhat elusive accountability of non-state actors under international law. While the liability of states should, depending on the special circumstances of every case, relate to compensation, repatriation and restitution, criminal responsibility of individuals, which is already an established feature under some existing international (humanitarian law) instruments, should be preserved. Compensation both for damage foreseen or actually caused ought to be assessed on a case-by-case basis.

A new convention should ideally provide redress for both individual and group claimants for damage caused to the natural environment during armed conflict. Redress should be in the form of either restitution or compensation. For the purpose of group or individual claims, states need not make a declaration ${ }^{221}$ to submit to the jurisdiction of the proposed court or tribunal, as jurisdiction should be compulsory. It is furthermore suggested that, to achieve greater protection of the environment in armed conflict, the new convention should expressly demilitarise forests, as the latter can under such circumstances absorb the various emissions associated with armed conflicts.

The drafting of a new convention should preferably be a joint exercise undertaken by the ICRC and UNEP, as both have an extensive and proven record of dedication to secure protection for the environment in armed conflict. The new convention may be adopted under the auspices of either the ICRC or UNEP: while the former's ethos of neutrality may well serve to secure greater acceptance by the international community, ${ }^{222}$ the proposed role assigned to the Security Council may well point to the latter as the preferred option.

secretariat and the Department for the Execution of Judgments of the European Court of Human Rights: see "The role of the Committee of Ministers" available at http://www.echr.coe.int/ ECHR/EN/Header/The+Court/How+the+Court+works/The+execution+of+judgments/ (accessed 14 April 2011).

221 As provided for expressly by, for example, Art 36(2) of the Statute of the ICJ, which states: "The states parties to the present Statute may at any time declare that they recognize as compulsory ipso facto and without special agreement, in relation to any other states accepting the same obligation, the jurisdiction of the Court in all legal disputes concerning: (a) the interpretation of a treaty; (b) any question of international law; (c) the existence of any fact which, if established, would constitute a breach of an international obligation; (d) the nature or extent of the reparation to be made for the breach of an international obligation". Art 36(3) stipulates that such declarations "may be made unconditionally or on condition of reciprocity on the part of several or certain states, or for a certain time". Declarations are to be deposited, in terms of Art 36(4), with the Secretary-General of the UN.

222 Although states displayed some reservation in the early 1990s for such a "dramatic metamorphosis of the lex scripta" and governments were generally reluctant to accept significant new obligations in this field, global concern about the natural environment has gained considerable momentum in the last decade. It need not be argued that the natural environment is under increased threat and this reality may well encourage the international community to reconsider its former position on the adoption of a new convention: see, in particular, Dinstein (2001) at 549 n 142. 
The adoption of an entirely new convention is indeed preferable to the mere drafting of a (fourth) additional protocol 223 to the four Geneva Conventions. A new convention would have the additional advantage of allowing errors, omissions or supplementary provisions to be augmented in a subsequent protocol - a standard practice in international law. Such a course of action would avert the proliferation of (additional) protocols or amendment protocols. However, should states fail to ratify the new convention, the rules and principles of customary international law, binding on the whole community of nations, would be applicable. Evidence ${ }^{224}$ that damage to the natural environment in armed conflict is prohibited under customary international law ${ }^{225}$ is clearly manifest in the fundamental principles of $I H L, 226$ including even possibly United Nations General Assembly Resolution 47/37 of 1992 which states that the "destruction of the environment not justified by military necessity and carried out wantonly, is clearly contrary to existing international law". ${ }^{227}$ It is to be hoped that these proposals will aid the international community to take the bold political decisions required to provide adequate and comprehensive protection to the natural environment in times of armed conflict.

\section{BIBLIOGRAPHY}

Advisory Opinion on the Legality of the Threat or Use of Nuclear Weapons 1996 ICJ Reports 226

Alford RP "Well blowout control claim" (1998) 92 American Journal of International Law 287

223 The three existing additional protocols to the four Geneva Conventions of 1949 include: (a) Additional Protocol I of 1977 on the protection of victims of international armed conflicts; (b) Additional Protocol II of 1977 on the protection of victims of non-international armed conflicts; and (c) Additional Protocol III of 2005 on the use of the three emblems (the red cross, red crescent and red crystal) of the ICRC during armed conflict. A fourth additional protocol would presumably be on the protection of the environment during armed conflict.

224 In contemporary times evidence of custom can be deduced from statements by the UN General Assembly without regard to state practice: see, in particular, James T "Customary law and ad hoc international criminal courts" available at http://www.allacademic.com//meta/p mla apa research citation/3/1/4/1/4pages314148/p314148-11.php [accessed 23 September 2010].

225 See para 65 and accompanying footnotes. See also, in general ICRC "A guide to the legal review of new weapons, means and methods of warfare: Measures to implement Article 36 of Additional Protocol I of 1977" 88 No 864 International Review of the Red Cross 931 at 938-945. For a discussion of these see, in particular, para 3 and para 65 and accompanying footnotes. "Protection of the environment in times of armed conflict" GA res 47/37, 47 UN GAOR Supp (No 49) 290, UN Doc A/47/49 (1992). 
Birnie P, Boyle A and Redgwell C International law and the environment 3ed Oxford: Oxford University Press (2009)

Bothe M, Bruch C, Diamond J and Jensen J "International law protecting the environment during armed conflict: gaps and opportunities" (2010) 92 No 879 International Review of the Red Cross 569

Bouvier A "Protection of the natural environment in time of armed conflict" (1991) 73 No 285 International Review of the Red Cross 567

Bouvier A "Protection of the environment in time of armed conflict" ICRC Report submitted to the $47^{\text {th }}$ session of the United Nations General Assembly 1 October 1992

Bouvier A "Recent studies on the protection of the environment in time of armed conflict" (1992) 74 No 291 International Review of the Red Cross 554

Bugnion F "The International Committee of the Red Cross and nuclear weapons: From Hiroshima to the dawn of the $21^{\text {st }}$ century" (2005) 87 No 859 International Review of the Red Cross 511

Cannizzaro E "Contextualizing proportionality: jus ad bellum and jus in bello in the Lebanese war" (2006) 88 No 864 International Review of the Red Cross 779

Case of the Military and Paramilitary Activities in and against Nicaragua (Nicaragua v US) (Merits) 1986 ICJ Reports 14

Cryer R, H Friman, D Robinson and E Wilmshurst (eds) An Introduction to International Criminal Law and Procedure 2 ed Cambridge: Cambridge University Press (2010)

Dinstein Y "Protection of the environment in international armed conflict" (2001) 5 Max Planck Yearbook of the United Nations Law 523

Dörmann K, Doswald-Beck L and Kolb R Elements of War Crimes under the Rome Statute of the International Criminal Court: Sources and Commentary Cambridge: Cambridge University Press (2003)

Dugard J International law: A South African perspective 3ed Cape Town: Juta \& Co Ltd (2005)

Gasser HP "For better protection of the natural environment in armed conflict: A proposal for action" (1995) 89 American Journal of International Law 637

Gasser HP "Guidelines for military manuals and instructions on the protection of the environment in times of armed conflict" (1996) 78 No 311 International Review of the Red Cross 230

Gill TD and Fleck D (eds) The Handbook of the International Law of Military Operations Oxford: Oxford University Press (2010) 
Henckaerts JM and Doswald-Beck L (eds) Customary International Humanitarian Law Vol I: Rules Cambridge: ICRC and Cambridge University Press (2005)

Henckaerts JM and Doswald-Beck L (eds) Customary International Humanitarian Law Vol II: Practice - Part 1 Cambridge: ICRC and Cambridge University Press (2005)

Henckaerts JM and Doswald-Beck (eds) L Customary International Humanitarian Law Vol III: Practice - Part 2 Cambridge: ICRC and Cambridge University Press (2005)

Hulme $\mathrm{K}$ "Taking care to protect the environment against damage: a meaningless obligation?" (2010) 92 No 879 International Review of the Red Cross 675

International Committee of the Red Cross "A guide to the legal review of new weapons, means and methods of warfare: Measures to implement Article 36 of Additional Protocol I of 1977" 88 No 864 International Review of the Red Cross 931

Infeld, DL "Precision-guided munitions demonstrated their pinpoint accuracy in desert storm; but is a country obliged to use precision technology to minimize collateral civilian injury and damage?" (1992) 26 (1) George Washington Journal of International Law and Economics 109

Kalshoven F and Zegveld L Constraints on the Waging of War: An Introduction to International Humanitarian Law Geneva: International Committee of the Red Cross (2001)

Kidd M Environmental law: A South African Guide Cape Town: Juta \& Co Ltd (1997)

Marauhn T "Environmental damage in times of armed conflict - not 'really' a matter of criminal responsibility" (2000) 82 No 840 International Review of the Red Cross 1029

McCormack TLH (ed) Yearbook of International Humanitarian Law The Hague: TMC Asser Press (2009)

Meron T Human Rights in Internal Strife: Their International Protection Cambridge: Grotius Publications Ltd (1987)

Mrema EM, Bruch C and Diamond J Protecting the Environment during Armed Conflict: An Inventory and Analysis of International Law United Nations Environment Programme 3ed Nairobi: United Nations Environment Programme (2009)

Oeter S "Method and means of combat" in D Fleck (ed) The Handbook of Humanitarian Law in Armed Conflicts Oxford: Oxford University Press (1995)

Quéguiner JF "Precautions under the law governing the conduct of hostilities" (2006) 88 No 864 International Review of the Red Cross 793

Reyhani R "The protection of the environment during armed conflict" (2007) 14 (2) Missouri Environmental Law and Policy Review 323 
Roberts A and Guelff R "Environmental modification techniques" in Roberts A and Guelff R (eds) Documents on the Laws of War 3ed Oxford: Oxford University Press (2000)

Roberts AE "Traditional and modern approaches to customary international law: A reconciliation" (2001) 95 American Journal of International Law 757

Sands P Principles of International Environmental Law (2003) Manchester: Manchester University Press

Sassòli M and Bouvier AA How does Law Protect in War? Cases, Documents and Teaching Materials on Contemporary Practice in International Humanitarian Law Vol I Geneva: International Committee of the Red Cross (2006)

Sassòli M and Bouvier AA How does Law Protect in War? Cases, Documents and Teaching Materials on Contemporary Practice in International Humanitarian Law Vol II Geneva: International Committee of the Red Cross (2006)

Schabas WA An Introduction to the International Criminal Court 2 ed Cambridge: Cambridge University Press (2004).

Schabas WA The International Criminal Court: A Commentary on the Rome Statute Oxford: Oxford University Press (2010)

Schmidt MN "Humanitarian law and the environment" (2000) 28 Denver Journal of International Law and Policy 265

Solis GD The Law of Armed Conflict: International Humanitarian Law in War Cambridge: Cambridge University Press (2010)

Strydom HA "Customary international law: The legacy of false prophets" (1994) 27 Comparative and International Law Journal of Southern Africa 276

Werle G Principles of International Criminal Law The Hague: TMC Asser Press (2005) Wilmshurst E and Breau S (eds) Perspectives on the ICRC study on Customary International Humanitarian Law Cambridge: Cambridge University Press (2007) 